\title{
Vegetation and climate history in the Laptev Sea region (Arctic Siberia) during Late Quaternary inferred from pollen records
}

\author{
Andrei A. Andreev ${ }^{\mathrm{a}, *}$, Lutz Schirrmeister ${ }^{\mathrm{a}}$, Pavel E. Tarasov ${ }^{\mathrm{b}}$, Andrey Ganopolski ${ }^{\mathrm{c}}$, Viktor Brovkin ${ }^{\mathrm{d}}$, \\ Christine Siegert ${ }^{\mathrm{a}}$, Sebastian Wetterich ${ }^{\mathrm{a}}$, Hans-Wolfgang Hubberten ${ }^{\mathrm{a}}$ \\ ${ }^{a}$ Alfred Wegener Institute for Polar and Marine Research, Research Unit Potsdam, Telegrafenberg A43, 14473 Potsdam, Germany \\ ${ }^{\mathrm{b}}$ Free University Berlin, Institute of Geological Sciences, Palaeontology Branch, Malteserstr. 74-100 Building D, 12249 Berlin, Germany \\ c Potsdam Institute for Climate Impact Research, Telegrafenberg A62, 14473 Potsdam, Germany \\ ${ }^{\mathrm{d}}$ Max Planck Institute for Meteorology, Bundesstr. 55, 20146 Hamburg, Germany
}

\section{A R T I C L E I N F O}

\section{Article history:}

Received 9 August 2009

Received in revised form

14 May 2010

Accepted 27 December 2010

Available online $\mathrm{xxx}$

\section{Keywords:}

Late Quaternary

Arctic Siberia

Pollen records

Vegetation and climate reconstruction

Earth-system model

\begin{abstract}
A B S T R A C T
Paleoenvironmental records from a number of permafrost sections and lacustrine cores from the Laptev Sea region dated by several methods $\left({ }^{14} \mathrm{C}\right.$-AMS, TL, IRSL, OSL and $\left.{ }^{230} \mathrm{Th} / \mathrm{U}\right)$ were analyzed for pollen and palynomorphs. The records reveal the environmental history for the last ca $200 \mathrm{kyr}$. For interglacial pollen spectra, quantitative temperature values were estimated using the best modern analogue method. Sparse grass-sedge vegetation indicating arctic desert environmental conditions existed prior to $200 \mathrm{kyr}$ ago. Dense, wet grass-sedge tundra habitats dominated during an interstadial ca 200-190 kyr ago, reflecting warmer and wetter summers than before. Sparser vegetation communities point to much more severe stadial conditions ca 190-130 kyr ago. Open grass and Artemisia communities with shrub stands (Alnus fruticosa, Salix, Betula nana) in more protected and moister places characterized the beginning of the Last Interglacial indicate climate conditions similar to present. Shrub tundra (Alnus fruticosa and Betula nana) dominated during the middle Eemian climatic optimum, when summer temperatures were $4-5{ }^{\circ} \mathrm{C}$ higher than today. Early-Weichselian sparse grass-sedge dominated vegetation indicates climate conditions colder and dryer than in the previous interval. Middle Weichselian Interstadial records indicate moister and warmer climate conditions, for example, in the interval 40-32 kyr BP Salix was present within dense, grasssedge dominated vegetation. Sedge-grass-Artemisia-communities indicate that climate became cooler and drier after $30 \mathrm{kyr}$ BP, and cold, dry conditions characterized the Late Weichselian, ca 26-16 kyr BP, when grass-dominated communities with Caryophyllaceae, Asteraceae, Cichoriaceae, Selaginella rupestris were present. From 16 to 12 kyr BP, grass-sedge communities with Caryophyllaceae, Asteraceae, and Cichoriaceae indicate climate was significantly warmer and moister than during the previous interval. The presence of Salix and Betula reflect temperatures about $4{ }^{\circ} \mathrm{C}$ higher than present at about $12-11 \mathrm{kyr}$ BP, during the Allerød interval, but shrubs were absent in the Younger Dryas interval, pointing to a deterioration of climate conditions. Alnus fruticosa, Betula nana, Poaceae, and Cyperaceae dominate early Holocene spectra. Reconstructed absolute temperature values were substantially warmer than present (up to $12{ }^{\circ} \mathrm{C}$ ). Shrubs gradually disappeared from coastal areas after $7.6 \mathrm{kyr}$ BP when vegetation cover became similar to modern. A comparison of proxy-based paleoenvironmental reconstructions with the simulations performed by an Earth system model of intermediate complexity (CLIMBER-2) show good accordance between the regional paleodata and model simulations, especially for the warmer intervals.
\end{abstract}

() 2011 Elsevier Ltd. All rights reserved.

\section{Introduction}

Climate simulations that predict a strong increase of air temperatures in Arctic in the nearest future underline the importance

\footnotetext{
* Corresponding author. Present address: University of Cologne, Institute of Geology and Mineralogy, Zuelpicher Str. 49a, D-50674 Cologne, Germany. Tel.: +49 3312882156.

E-mail address: Andrei.Andreev@awi.de (A.A. Andreev).
}

of understanding environmental dynamics in the high latitudes (e.g. ACIA, 2005; ACIS, 2008). The predicted warming involves positive global feedback processes such as decreasing albedo due to reduced sea ice and snow cover; it may result in thawing of permafrost in Arctic Siberia containing organic material that has been stored over thousands of years. Therefore, frozen Siberian landmasses may turn into a significant source of greenhouse gases (Zimov et al., 2006a,b; Walter et al., 2007; Schuur et al., 2009). As regions of Arctic Siberia may play a key role in future climate

0277-3791/\$ - see front matter (c) 2011 Elsevier Ltd. All rights reserved. doi:10.1016/j.quascirev.2010.12.026 
changes it is desirable to understand natural, long-term environmental trends on various time scales. Quaternary sediments containing bioclimatic indicators are widely used to reconstruct climatic and other environmental conditions such as vegetation pattern, treeline positions or landscape evolution. Pollen records play a leading role among bioindicators mainly because of the common presence of fossil pollen in Quaternary terrestrial periglacial and lacustrine deposits. Moreover, they are relatively easy to obtain, and they provide a basis for qualitative and numerical reconstructions of past environments.

Continuous lacustrine records are most suitable for reconstructing long-term paleoenvironmental dynamics, but vast regions in the Northern Hemisphere are still poorly investigated because of a lack of such archives. However, other sources of information are available. In Arctic regions, especially in Siberia, permafrost deposits have been increasingly used over the past few decades. Generally, such deposits are excellent paleoecological archives and contain numerous bioindicators, such as pollen, nonpollen palynomorphs, diatoms, rhizopods, ostracods, mammal bones, plant macrofossils and insect remains. This makes them an invaluable source of long paleoenvironmental records. In the Laptev Sea region (Fig. 1), investigations have been carried out since
1998 under the framework of the joint Russian-German scientific collaboration "System Laptev Sea". The main aim is the characterization of the paleoenvironments that predominated during cold episodes and were characterized by vegetation communities combining cold Arctic tundra and dry steppe elements (so-called tundra-steppe, e.g. Yurtsev, 2001; Sher et al., 2005). In these studies, cliffs along coasts of the Laptev Sea and the Dmitri Laptev Strait and riverbanks in the Lena Delta exposed by erosion provided access to frozen sedimentary records of different ages. A range of proxies, such as cryolithological characteristics of the sediment, geochemistry of the ground ice, and fossil bioindicators have been used (for overview see SOM 1). In addition, continuous lake-sediment core records from more inland areas were collected and analyzed. These joint multi-disciplinary studies have greatly improved our knowledge about the Late Quaternary paleoenvironment in the Laptev Sea region (e.g. Andreev et al., 2001a,b, 2002a,b,c, 2003, 2004a,b, 2009; Schirrmeister et al., 2002a, 2003, 2008, 2010, 2011, in press; Grosse et al., 2007; Ilyashuk et al., 2006; Kienast et al., 2005, 2008, in press; Wetterich et al., 2005, 2008, 2009 and references therein).

The main focus of this paper is to provide an overview of vegetation and climate changes in the Laptev Sea area and surrounding

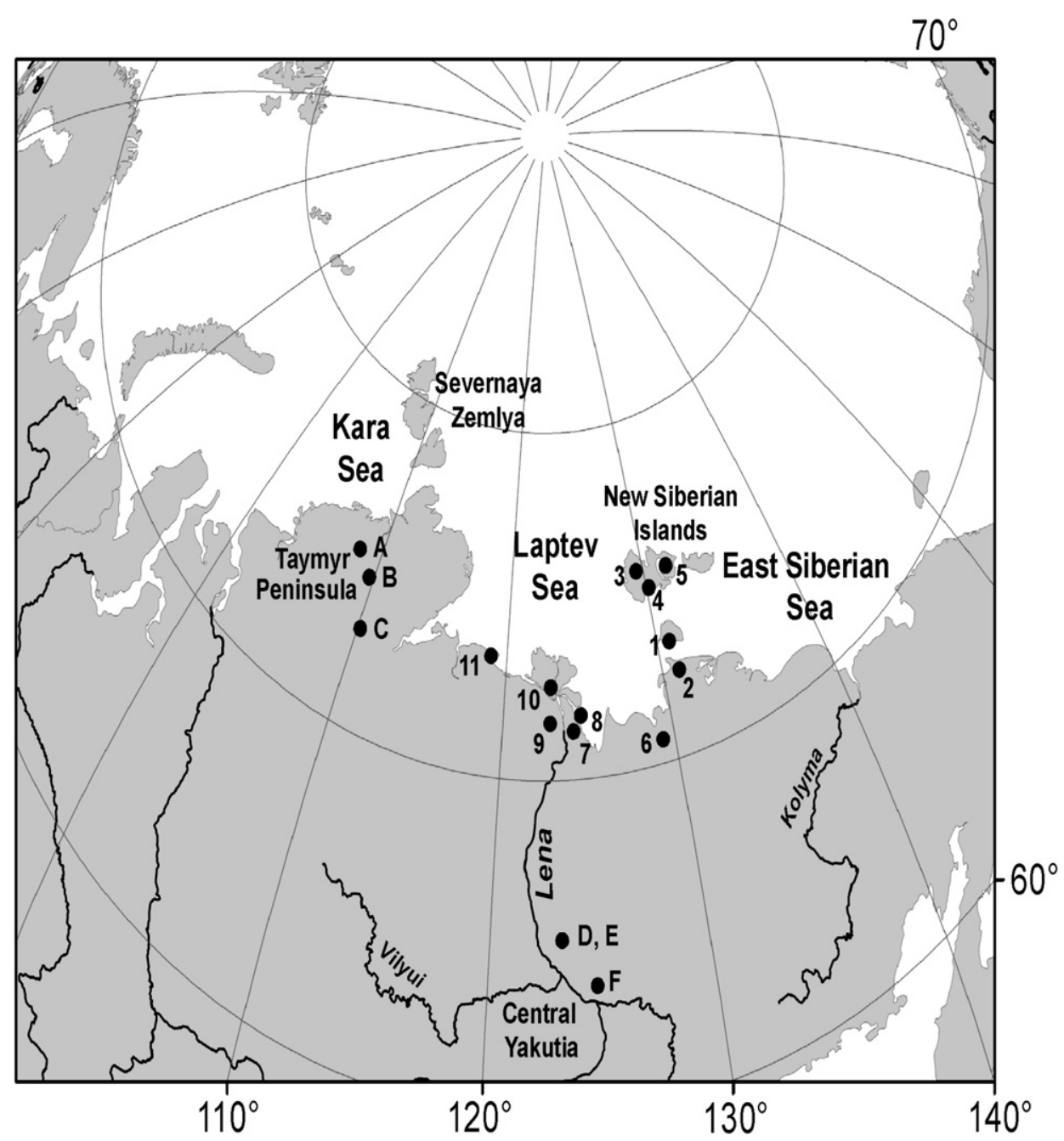

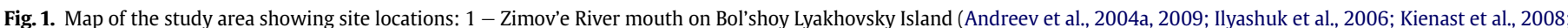

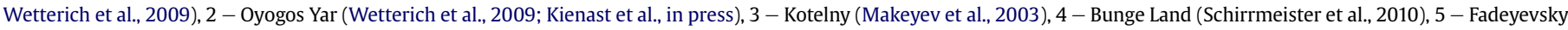

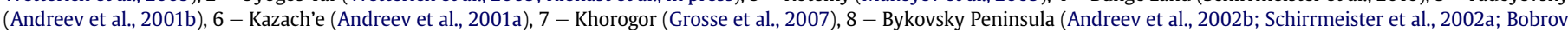

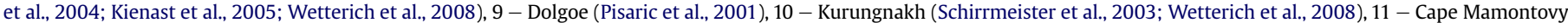

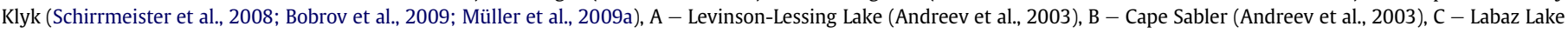
(Andreev et al., 2002c), D - Billyakh Lake (Müller et al., 2009b, 2010), E - Dyanushka River (Zech et al., in press). F - Tumara River (Zech et al., 2010). 
regions during the past $200 \mathrm{kyr}$. For the East Siberian arctic lowlands the stratigraphic classification of this period is based mostly on previous palynological (e.g. Giterman et al., 1982; Kaplina and Lozhkin, 1984) and paleozoological (e.g. Sher, 1971; Vangengeim, 1977 ) as well as cryolithological (e.g. Kaplina, 1981, 1989) data sets. Studies on numerous local profiles resulted in separate individual stratigraphical schemes often with individual names for single suites, layers or horizons, which are correlated for further chronological-stratigraphic classification (e.g. Ivanov, 1972; Sher et al., 1987). Nevertheless, for some periods, the stratotypes, as well as their absolute chronology and the paleoenvironmental interpretation of their bioindicator records, are still under discussion (e.g. Astakhov, 2001). Because the regional stratigraphy of northeastern Siberia is still unclear (e.g. Sher and Plakht, 1988; Astakhov and Mangerud, 2005; Astakhov, 2001, 2004, 2006) we have waived use of the Russian classification, using instead European nomenclature and the marine-isotope (MIS) time scale (Table 1; Velichko and Nechaev, 2005; Sirocko et al., 2007; Gibbard and Cohen, 2008; Andreev et al., 2009; ICS, 2010 and references therein). Our paleoenvironmental reconstructions are also compared to CLIMBER-2 model simulations (Ganopolski, 2005), in particular focusing on the consistency, or otherwise, of reconstructions based on the paleodata and model simulation results. Detailed geological, geomorphologic, sedimentological, and lithological descriptions of the study sites, their chronostratigraphy based on ${ }^{14} \mathrm{C}$-AMS, TL, IRSL, OSL, ${ }^{230} \mathrm{Th} / \mathrm{U}$, and paleomagnetic data, as well as descriptions of methods and techniques are already published. In this paper, we synthesize the published data; readers are referred to the cited works for information on individual study sites and analytic methods.

\section{Regional setting}

The study area (here referred to as the Laptev Sea region; Fig. 1) includes Arctic and subarctic areas around the Laptev Sea from the eastern Taymyr Peninsula (approximately $74^{\circ} \mathrm{E}$ ) to the Dmitri Laptev Strait (approximately $150^{\circ} \mathrm{E}$ ). Arctic climate conditions prevail. The climate is characterized by long (8-9 months), severe winters with mean January temperatures around -30 to $-32{ }^{\circ} \mathrm{C}$ and short (2-3 month), cool summers with mean July temperatures around $3-4{ }^{\circ} \mathrm{C}$ (Atlas Arktiki, 1985). The climate is more continental in the southern interior, where summer temperatures may reach up to $10-12{ }^{\circ} \mathrm{C}$. Annual precipitation reaches $300 \mathrm{~mm}$ in western part of the region and gradually decreases (to ca $200 \mathrm{~mm}$ ) in the northeast direction. The study region belongs to the zone of continuous permafrost and is characterized by frozen ground up to several hundred meters deep (Geocryological Map, 1996; Williams and Warren, 1999).

Soils in the area are mainly histosols and inceptisols and typically display gleyed horizons with an active-layer thickness of about 30-40 cm (Atlas Arktiki, 1985). The area belongs to the northern tundra zone (Atlas Arktiki, 1985; CAVM Team, 2003). Moss-grass/low-shrub tundra dominates the vegetation, with vascular plant species such as Salix pulchra, Cassiope tetragona,
Dryas punctata, Oxyria digyna, Alopecurus alpinus, Poa arctica, Carex ensifolia, C. rotundifolia, and Eriophorum medium, mosses such as Aulacomnium turgidum, Hylocomium alaskanum, Drepanocladus iniciatus, and Calliergon sarmentosum, and lichens such as Alectoria ochroleuca, Cetraria cuculliata, and C. hiascus. Dwarf birch shrubs (Betula nana s.l.) and shrub alder (Alnus fruticosa) are absent in the coastal zone but gradually become more common southwards.

\section{Methods}

Localities were sampled for paleoecological studies (e.g. pollen, plant macrofossils, insects, rhizopods, ostracods; SOM 1), age determinations (see below), and sedimentological, paleomagnetic and ground-ice studies. As descriptions of the methods are published in detail elsewhere (see above), here we focus on the palynological methods, as pollen data are central to our interpretations, modeling procedures, and the numerical methods used to reconstruct climate variables from pollen data and to compare the reconstructions with model simulations.

The stratigraphy of the studied sections is based on the vertical and lateral composition of the studied sequences and relationships of separate lithostratigraphic units, which were already observed during field studies. Afterwards, such studies were completed and generalized by multi-disciplinary sediment and ground ice analyses as well as by biostratigraphical characteristics. (Sections were related vertically and laterally via lithostratigraphy observed in the field plus sedimentological and biostratigraphical characteristics determined by subsequent analyses.)

Geochronological results of several dating methods: radiocarbon accelerator mass spectrometry $\left({ }^{14} \mathrm{C}\right.$-AMS), thermoluminescence (TL), infrared stimulated luminescence (IRSL), optically stimulated luminescence: (OSL), and thorium-uranium disequilibrium $\left({ }^{230} \mathrm{Th} / \mathrm{U}\right)$, which have overlapping temporal ranges, were used to support stratigraphic interpretations. Although different geochronological methods do not always give consistent results due to disturbances related to thermokarst, erosion and cryoturbation and other problems encountered in permafrost dating, general stratigraphical trends and classifications were evident. We interpret the chronologies with these known complications in mind. The final stratigraphic scheme presented here is a compilation of lithostratigraphical, biostratigraphical, and chronostratigraphical information.

A standard HF technique was used for pollen preparation (Berglund and Ralska-Jasiewiczowa, 1986). One tablet of Lycopodium marker spores was added to each sample (except for the samples from Bykovsky Peninsula, see Andreev et al., 2002b) for calculating total pollen and spore concentrations following Stockmarr (1971). Water-free glycerol was used for sample storage and preparation of the microscopic slides. Pollen and spores were identified at magnifications of $400 \times$ and $1000 \times$, with the aid of published pollen keys and atlases (Kupriyanova and Alyoshina, 1972, 1978; Bobrov et al., 1983; Reille, 1992, 1995, 1998; Beug, 2004). In addition to pollen and spores a number of so-called

Table 1

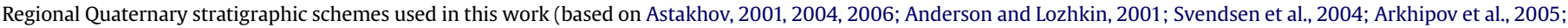
Lambeck et al., 2006; Lozhkin et al., 2007; Gibbard and Cohen, 2008; ICS, 2010, Sirocko et al., 2007; Velichko and Nechaev, 2005).

\begin{tabular}{|c|c|c|c|c|}
\hline Ages [kyr] & $\begin{array}{l}\text { Siberian } \\
\text { nomenclature }\end{array}$ & $\begin{array}{l}\text { West European } \\
\text { nomenclature }\end{array}$ & $\begin{array}{l}\text { North American } \\
\text { nomenclature }\end{array}$ & $\begin{array}{l}\text { Marine Isotope Stages } \\
\text { (MIS) }\end{array}$ \\
\hline ca $10.3-0$ & Holocene & Holocene & Holocene & MIS 1 \\
\hline ca $30-10.3$ & Sartan & Late Weichselian & Late Wisconsinan & MIS2 \\
\hline ca $50-30$ & Karginsky & Middle Weichselian & Middle Wisconsinan & MIS3/MIS4 \\
\hline ca $110-50$ & Ermakovo, Zyryan & Early Weichselian & Early Wisconsinan & MIS4/MIS5a-d \\
\hline ca $130-115$ & Kazantsevo & Eemian & Sangamonian & MIS5e \\
\hline ca $200-130$ & Tazovsky & Late Saalian & Illinoian & MIS6/MIS7 \\
\hline
\end{tabular}


non-pollen palynomorphs, such as fungal spores and remains of algae and invertebrates, were also identified and counted when possible. These non-pollen palynomorphs can also be used for interpretation of past environments (e.g. Van Geel, 2001 and references therein).

At least 200 to 250 pollen grains were counted in every sample. In samples with extremely low concentrations up to 100 pollen grains were counted. The relative frequencies of pollen taxa were calculated from the sum of the terrestrial pollen taxa. Spore percentages are based on the sum of pollen and spores. The interpretation of Sordariaceae spores (coprophilous fungi) as indicators for grazing mammals is based on their preference for specific habitats on mammal dung (e.g. Wicklow, 1981). The relative abundances of reworked taxa (Tertiary spores and redeposited Quaternary pollen) are based on the sum of pollen and redeposited taxa, the percentages of non-pollen palynomorphs are based on the sum of the pollen and non-pollen palynomorphs, and the percentages of algae are based on the sum of pollen and algae. The Tilia/TiliaGraph software (Grimm, 1991) was used for the calculation of percentages and for drawing the diagrams. The diagrams were zoned by a qualitative inspection of significant changes in pollen associations, pollen concentration and the occurrence of particularly indicative taxa (e.g. tree pollen).

The best modern analogue (BMA) method (Guiot, 1990) has been used to reconstruct climate characteristics from the pollen spectra attributed to the Eemian and the Holocene. The method has been successfully applied to Lateglacial and Holocene pollen records from the Russian Arctic (e.g. Andreev and Tarasov, 2007 and references therein). The accuracy of the BMA method in comparison with other pollen-based reconstruction approaches is discussed in Andreev et al. (2003). In the present study, we used the same reference data sets and calculation techniques as described in Andreev et al. (2003, 2004a,b) and in Tarasov et al. (2005, 2007, 2009). Mean July temperature as mean temperatures of the warmest month (MTWM), and the annual sum of mean-day temperatures above $5^{\circ} \mathrm{C}$ (GDD5) have the most definitive effect on Arctic vegetation (Kaplan, 2001; Kienast et al., 2008) and can be reconstructed from surface (and fossil) pollen spectra from the Russian Arctic with the relatively high confidence (Andreev et al., 2003).

We compared proxy-based paleoclimate and paleoenvironmental reconstructions with simulations produced by an earth system model (ESM) of intermediate complexity, CLIMBER-2. The model includes a coarse-resolution (ca $10 \times 50^{\circ}$ ) spatial grid climate component described by Petoukhov et al. (2000) coupled fully interactively and bi-directionally to the 3-dimensional thermomechanical ice sheet model SICOPOLIS (Greve, 1997), which has a spatial resolution of ca $70 \mathrm{~km}$. The physically based surfaceenergy and mass-balance interface and the procedure for coupling between climate and ice sheet components are described in detail in Calov et al. (2005) and Ganopolski et al. (2010).

CLIMBER-2 includes reduced-form dynamical vegetation model VECODE, which simulates changes in vegetation structure and terrestrial carbon pools on a time scale from decades to millennia (Brovkin et al., 2002). VECODE describes vegetation cover as a mixture of two basic plant functional types (PFT), trees and grasses, and is based on fractional bioclimatic classification developed for coarse-resolution climate models (Brovkin et al., 1997). Two basic plant functional types (PFT), trees and grasses were used in this study. The sum of tree fraction (f) and grass fraction ( $g$ ) is equal to vegetation fraction $(v)$, the rest is desert fraction $(d=1-v)$. These transient land cover fractions differ from equilibrium fractions of PFTs that have been used in other approaches to create discrete bioclimatic classifications (e.g. the biome approach used by Prentice et al., 1992 and Kaplan et al., 2003). CLIMBER-2 is capable of simulating the basic global patterns of changes in natural vegetation cover during the last 8000 years (Brovkin et al., 2002).

The CLIMBER-2 model was recently successfully used to simulate the last glacial cycle (Ganopolski et al., 2010). For our datamodel comparison we use results for the last $200 \mathrm{kyr}$ from a 400 kyr-longer simulation covering the past four glacial cycles described in Bauer and Ganopolski (2010). The model was forced by variations of orbital parameters (Berger, 1978) and greenhouse gas concentrations obtained from the Vostok ice core (Petit et al., 1999). The simulation starts at $400 \mathrm{kyr}$ BP from the equilibrium interglacial initial conditions corresponding to MIS11 and the model was run fully interactively through to the present.

\section{Regional vegetation and environmental history based on the pollen records}

Here we briefly describe the sequence of major environmental changes synthesized from the suite of data collected from the study sites, with particular reference to reconstructed vegetation and inferred climatic conditions. The records span at least the last 200 kyr.

\subsection{Late Saalian stadial (>200 kyr, MIS $7 b$ ?)}

The oldest pollen spectra from the region were found on Bol'shoy Lyakhovsky Island (Andreev et al., 2004a; Fig. 1, site 1). Pollen spectra of pollen zone (PZ) I in Fig. 2 reflect sparse grass-sedge vegetation cover. Relatively high values of Asteraceae and Cichoriaceae, as well as large amounts of mineralized ancient Pinaceae pollen, indicate the presence of disturbed soils and erosion of older deposits. Based on pollen-based stratigraphy of the studied sediments this cold interval is assigned to a stadial during Saalian time (MIS 7).

\subsection{Late Saalian (Tazovsky) interstadial (ca 200 to 190 ? kyr, MIS 7a?)}

The deposits accumulated during this interval are characterized by thick peat horizons and numerous peaty lenses. According to the ${ }^{230} \mathrm{Th} / \mathrm{U}$ date from the $\mathrm{R} 8+50$ section (Fig. 3), peat accumulation occurred ca $200 \mathrm{kyr}$ ago. This age seems to be reliable as frozen peat is considered to be a closed system for uranium and thorium (Schirrmeister et al., 2002b). Paleomagnetic investigations showed that samples from the studied sections are reversely magnetized and, therefore, can be attributed to the Biwa I reversal event (ca 179-189 kyr, Nowaczyk and Antonow, 1997). Both, the ${ }^{230} \mathrm{Th} / \mathrm{U}$ date and the paleomagnetic data (Andreev et al., 2004a)are in a good agreement suggesting that this interval can belongs probably to the MIS 7a stage.

Poaceae and Cyperaceae dominate pollen assemblages from sediments accumulated on Bol'shoy Lyakhovsky Island following the stadial interval (Andreev et al., 2004a; PZ II of Fig. 2 and PZ I of Fig. 3). High pollen concentrations and low amounts of redeposited pollen and spores indicate relatively high productivity of local habitats, and we infer that open, wet grass-sedge tundra dominated the area.

Generally, the pollen spectra are similar to palynological records attributed to the end of the Middle Pleistocene reported from the locations around the Laptev Sea and some southern areas (e.g. Barkova, 1990 and references therein). Pollen spectra from the Tumara River in the southern foreland of Verkhoyansk Mountains (Fig. 1, site F), IRSL-dated to $220 \pm 20 \mathrm{kyr}$, also reflect open vegetation represented by sedges, grasses and a few willow stands (Zech et al., 2010). Other fossil bioindicators such as rhizopods and beetle remains reflect climate conditions slightly warmer and wetter 


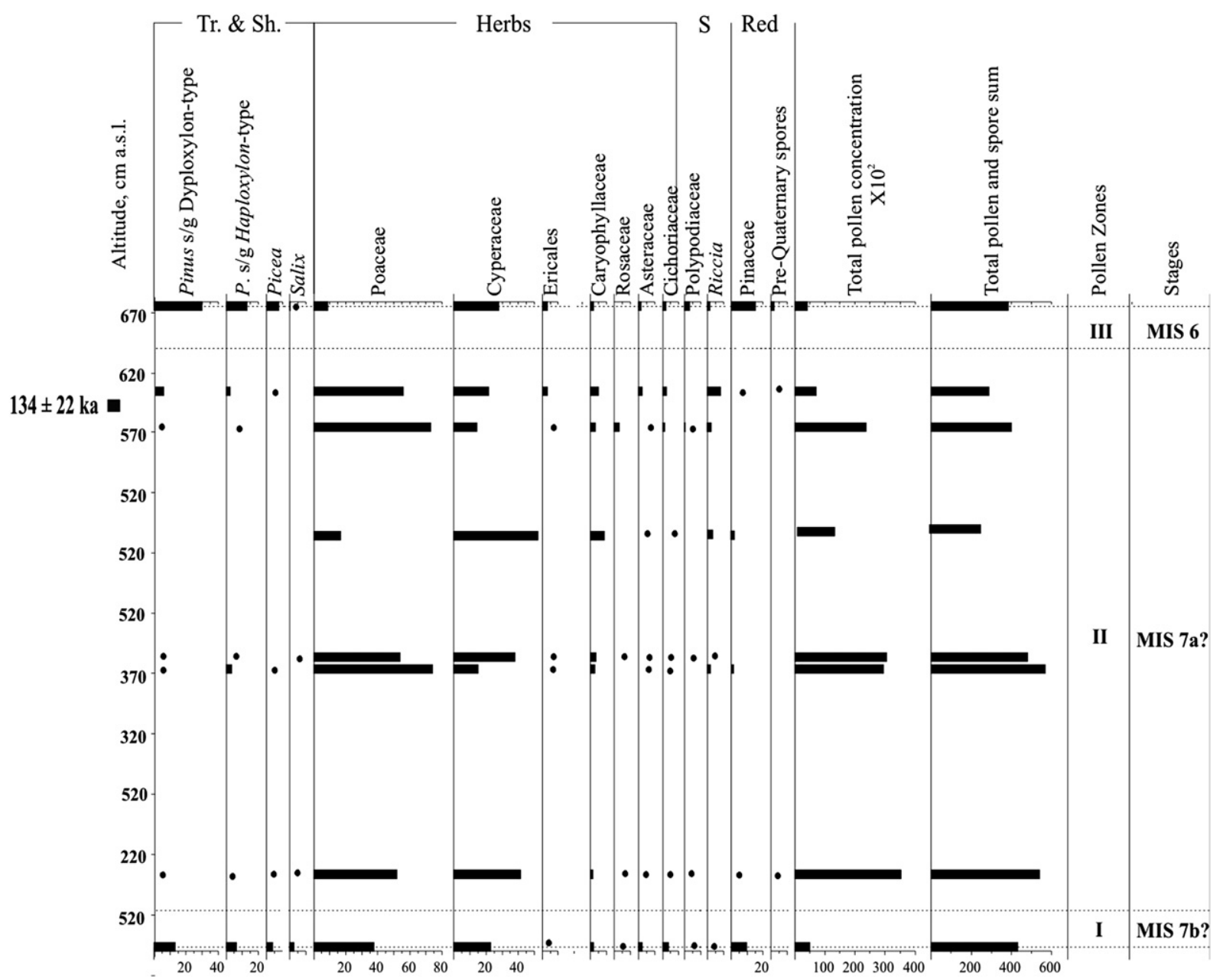

Fig. 2. Early/Late Saalian simplified pollen record from B. Lyakhovsky Island (site 1): • pollen percentages $<1$, Tr. \& Sh. - trees and shrubs, $\mathrm{S}-$ spores, Red - redeposited.

summers than today. Overall the data indicate tundra habitats ecologically similar to modern ones during the late Saalian Interstadial (Andreev et al., 2004a).

\subsection{Pre-Eemian stadial (ca 190? to 130 ? kyr, MIS 6?)}

The pollen spectra in deposits on the Bol'shoy Lyakhovsky Island (Fig. 1, site 1; Andreev et al., 2004a) accumulated ca 190-130 kyr BP (PZ III of Fig. 2, PZ II of Fig. 3, subprofile A of Fig. 4) reflect colder and drier environmental conditions compared to the previous interstadial. Based on the pollen and the lithostratigraphical data we may assume that this interval belongs to the MIS 6 stage. The IRSL date of $134 \pm 22 \mathrm{kyr}$ from the upper part of the studied Saalian section (Fig. 2) is in good agreement with the suggested late Saalian age of the deposits.

Two IRSL dates of $99 \pm 15$ and $102 \pm 16 \mathrm{kyr}$ from subprofile A in Fig. 4 (just below ice-wedge cast features) are still compatible with a late Saalian age of the lowest deposits. They suggest an Eemian age for overlying ice-wedge cast lacustrine sediments. An explanation for their relatively young ages is that the sediments below the ice-wedge cast were thawed during the existence of an Eemian lake and later refroze; these processes possibly influenced the physical and chemical properties of the sediments causing young IRSL ages to be recorded.

The spectra linked to the stadial interval are characterized by relatively low pollen concentrations and suggest sparse vegetation cover dominated by grass and sedge and/or a dramatic decrease of pollen production in more closed communities. Relatively high contents of Equisetum, Riccia, and Encalypta spores in some samples as well as large amounts of reworked pollen may mirror the presence of disturbed soils and the erosion of older deposits. High content of green algae colonies points to deposition under shallow water conditions (probably a floodplain environment). Large amounts of the dung-inhabiting Sordariaceae fungi spores in some samples may indicate the occurrence of herbivore herds in the area during that time, at least during some short intervals (Andreev et al., 2004a). The reconstruction of an extremely cold climate during the late Saalian based on the pollen data is also supported by stable water isotope analyses of respective ground ice (i.e. ice wedges, Meyer et al., 2002a).

\subsection{Eemian (Kazantsevo) interglacial (ca 130?-110? kyr, MIS 5e)}

Only fragmentary, discontinuous Eemian paleoecological records have been found in the study region; Eemian deposits are typically preserved within buried ice-wedge casts and this hinders the reconstruction of short-term environmental fluctuations during the interglacial. Nevertheless, the amalgamation of several local records enables some conclusions about Eemian vegetation and climate to be drawn.

On Bol'shoy Lyakhovsky Island pollen data derived from the base of buried ice-wedge casts (subprofile B of Fig. 4; Andreev et al., 2004a; Ilyashuk et al., 2006), indicates open Poaceae and Artemisia steppe or tundra-steppe habitats at the beginning of the interglaciation; this is consistent with the fossil insect records (Andreev 


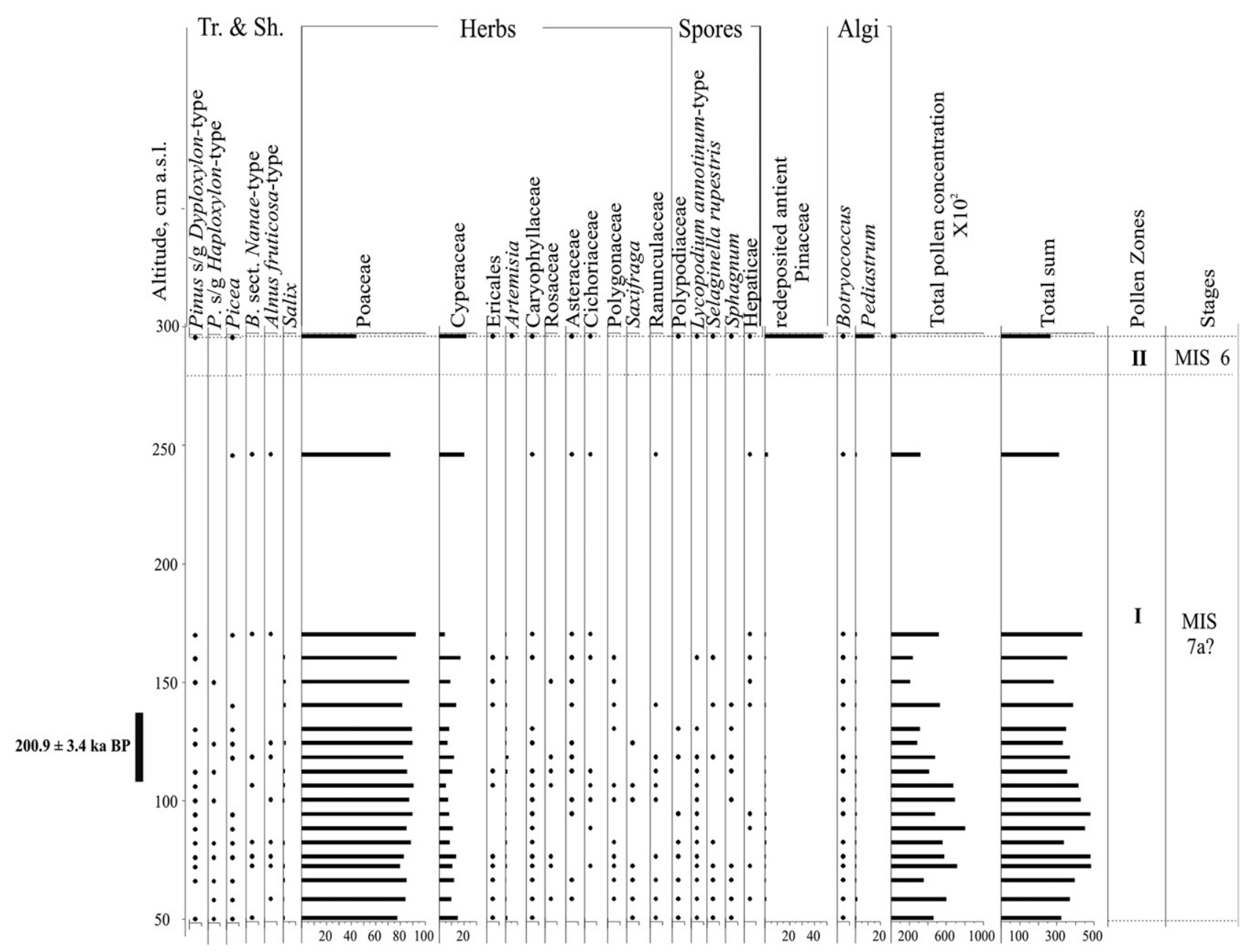

Fig. 3. Early Saalian interstadial simplified pollen record from B. Lyakhovsky Island (site 1 ): • pollen percentage $<1$, Tr. \& Sh. - trees and shrubs.

et al., 2004a). The high content of Artemisia pollen may also indicate that disturbed and/or denuded soils were locally common. Relatively high abundances of Alnus fruticosa, Salix, and Betula nana pollen indicate that shrub thickets likely grew in more protected places. The rather numerous coprophilous fungi (Sordariaceae) spores may indicate the presence of grazing herds around the studied sites. Pollen-based climate reconstructions show that temperatures during this time were similar to modern resulting in the partial melting of Saalian ice wedges; however, climate was drier than modern (Andreev et al., 2004a).

During the early/middle Eemian the pollen spectra at the Bol'shoy Lyakhovsky Island were dominated by Poaceae, Cyperaceae, Betula sect. Nanae, and Alnus fruticosa (PZ I of subprofile C of Fig. 4 Andreev et al., 2004a; Ilyashuk et al., 2006; Wetterich et al., 2009), reflecting a shrub-tundra environment. Relatively high amounts of Artemisia and the presence of herb pollen taxa such as Brassicaceae, Caryophyllaceae, and Asteraceae show that open plant associations were also common. High amounts of Glomus spores indicate that the vegetation cover was frequently disturbed, probably due to active erosion processes connected with thawing the Saalian ice wedges and the formation of thermokarst lakes. Dung-inhabiting Sordariales fungi spores present in many spectra indirectly point to presence of mammalian herbivores.

The Last Interglacial plant macrofossil assemblages reflect a rich flora consisting mainly of subarctic shrub tundra taxa (Kienast et al., 2008). High abundances of Alnus fruticosa and Betula pollen in middle Eemian sediments, as well as the numerous remains of fossil twigs, point to shrub tundra vegetation and relatively warm summers. Remains of chironomids and caddis flies, plus freshwater ostracod and mollusc shells (Wetterich et al., 2009) indicate the existence of shallow thermokarst lakes with a boggy catchment area around the studied sites. The high abundance of thermophilous chironomid taxa indicates relatively high summer air temperatures during the middle Eemian (Andreev et al., 2004a; Ilyashuk et al., 2006).

Middle Eemian pollen assemblages from the Oyogos Yar coast (Fig. 1, site 2; Wetterich et al., 2009) are dominated by pollen of Poaceae, Cyperaceae, Larix, Alnus fruticosa, Betula sect. Nanae and spores of Equisetum, dung-inhabiting Sordariaceae, and Glomus (Fig. 5, Wetterich et al., 2009). Based on relatively high amounts of Larix pollen, we assume that larch forest or forest-tundra with shrub alder and dwarf birch stands dominated vegetation around the Oyogos Yar site. Furthermore, numerous plant remains found in sediments attributed to Middle Eemian time indicate the local existence of forest with larch, alder and birches (Betula fruticosa, $B$. divaricata, $B$. nana; Kienast et al., in press). We conclude that treeline was displaced northward as far as the modern coast, and probably beyond, which is at least $270 \mathrm{~km}$ northward of its current position. Remains of beetles also point to a forested environment during the Last Interglacial at today's mainland coast. However, steppe plant and beetle remains show that tree stands were interspersed with patches of steppes and meadows (Kienast et al., in press).

Eemian pollen records from the IRSL-dated submarine and coastal permafrost cores drilled near Cape Mamontovy Klyk in the western 

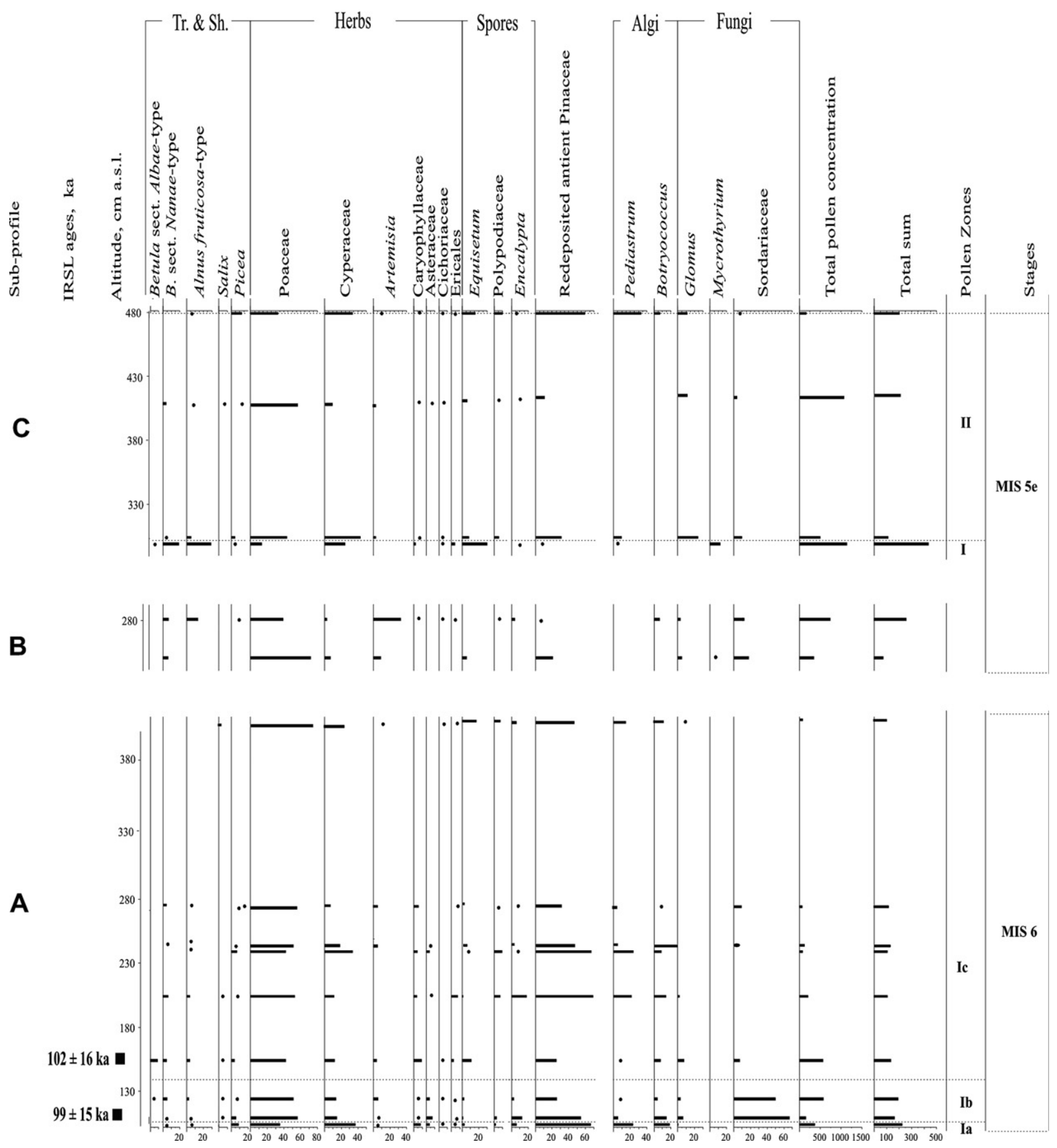

Fig. 4. Late Saalian and Last Interglacial simplified pollen record from B. Lyakhovsky Island (site 1 ): • pollen percentage $<1$, Tr. \& Sh. - trees and shrubs.

part of the Laptev Sea area (Fig. 1, site 11; Andreev, unpublished; Winterfeld et al., in press) and in the Dyanushka and Tumara River valleys in the Verkhoyansk Mountain foreland (Fig.1, site D, Zech et al., in press; site F, Zech et al., 2010) also reflect tree-dominated vegetation and indicate interglacial environmental conditions and warmer-thanpresent temperatures during the Last Interglacial optimum.

Quantitative pollen-based temperature reconstructions conducted on the Bol'shoy Lyakhovsky Island Eemian pollen records (Andreev et al., 2004a; Kienast et al., 2008) are consistent with the qualitative interpretation of the bioindicator records. The reconstructed mean July temperatures range from 7.8 to $9.6{ }^{\circ} \mathrm{C}$. Hence, the July temperatures were at least $4-5{ }^{\circ} \mathrm{C}$ higher than today during the Eemian climate optimum. However, estimates based on plant macrofossil remains suggest that summer temperatures may have been up to $10^{\circ} \mathrm{C}$ higher than the modern (Kienast et al., 2008).

Increases in the abundances of herb pollen and decreases in shrub and tree pollen in the overlying sediments indicate climate deterioration during the late Eemian in the area of Bol'shoy Lyakhovsky Island (PZ II in subprofile C of Fig. 4, Andreev et al., 2004a; Ilyashuk et al., 2006; Wetterich et al., 2009). Temperature reconstructions from pollen spectra attributed to the late Eemian suggest significantly cooler (similar to present day) conditions in comparison to the early-middle Eemian climate conditions (Andreev et al., 2004a; Kienast et al., 2008)

Generally, Last Interglacial pollen records are quite well known in northern Yakutia and adjacent regions (e.g. Rybakova, 1962; Rybakova and Kolesnikov, 1983; Pirumova and Rybakova, 1984; 


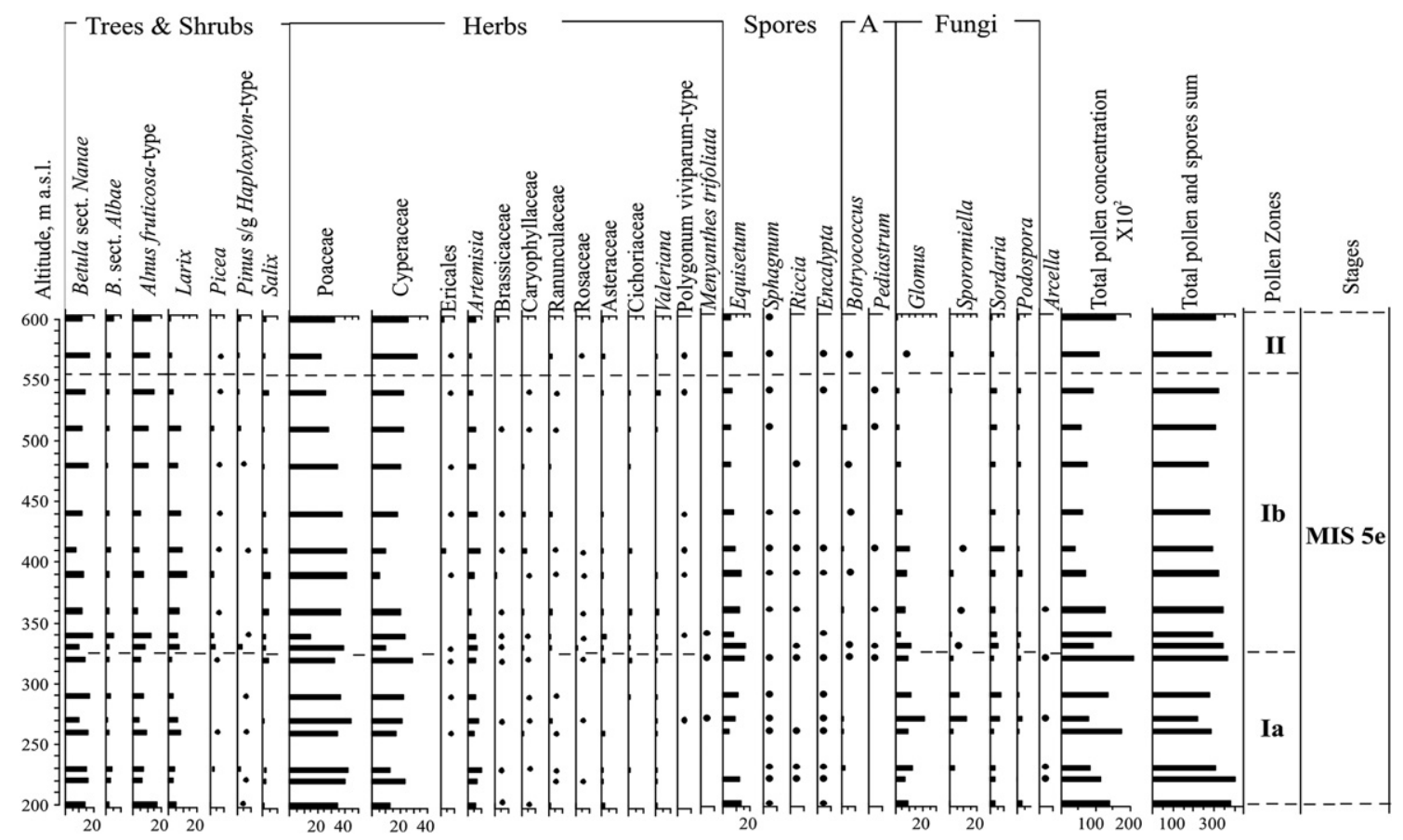

Fig. 5. Last Interglacial simplified pollen record from Oyogos Yar (site 2): • pollen percentage $<1, A-$ freshwater algae.

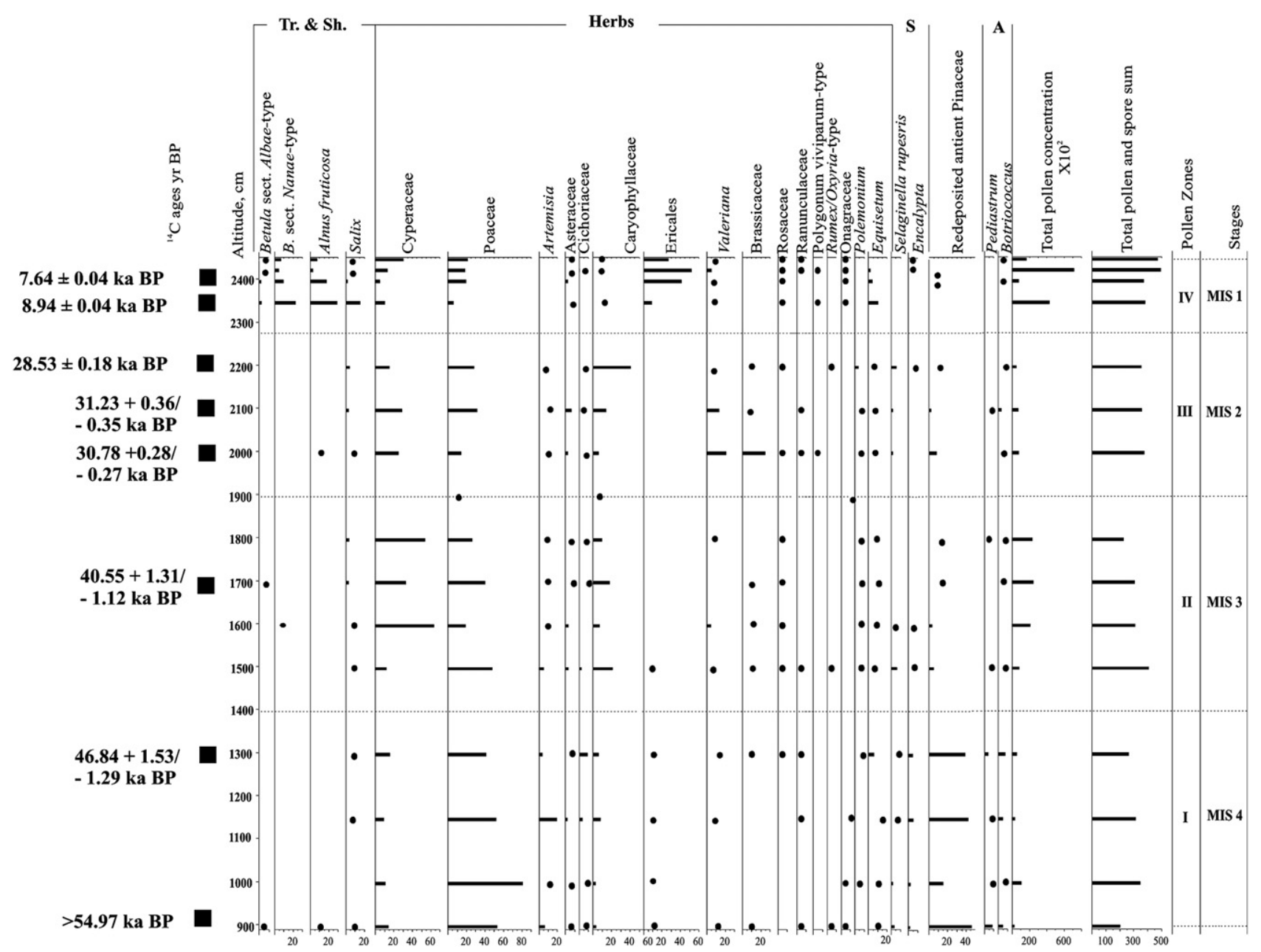

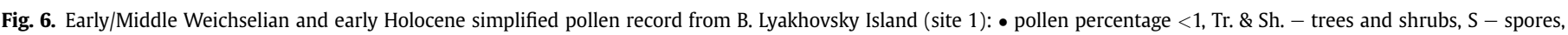
A - freshwater algae. 
Barkova, 1990; Sher, 1991, 1997; Lozhkin and Anderson, 1995; Lozhkin et al., 2007 and references therein). The spectra are characterized by high percentages of tree and shrub pollen, indicating that forest or tundra-forest vegetation dominated this region. However, our environmental records show that dry steppe-like habitats have also existed during the Eemian in northern Yakutia, especially during the early and the late Eemian. This is consistent with Andrei Sher's explanation of how the Pleistocene megafauna survived during the Last Interglacial (Sher, 1991, 1997). The presence of dung-inhabiting Sordariaceae in many pollen spectra also indirectly point to presence of grazing animal herds around the studied sites during the Eemian.

\subsection{Early Weichselian (Ermakovo, Zyryan) stadial (ca 110?-50 kyr,} MIS 5a-d, MIS 4)

Early Weichselian sediments are neither numerous nor well studied in the region. However, they are unusually abundant at the Bol'shoy Lyakhovsky site (Andreev et al., 2009; Fig. 1, site 1), at the Oyogos Yar coast (L. Schirrmeister, unpublished data; Fig. 1, site 2). They are also found on Bykovsky Peninsula (Andreev et al., 2002b; Schirrmeister et al., 2002a; Kienast et al., 2005; Fig. 1, site 8) and in the Lena Delta (Schirrmeister et al., 2003; Wetterich et al., 2008; Fig. 1, site 10). Early Weichselian pollen spectra (PZ-I of Fig. 6, the lowermost spectra from PZ-I of Fig. 7) containing mostly Poaceae and Cyperaceae pollen and numerous reworked ancient Pinaceae reflect harsh environmental conditions, sparse vegetation (mostly grass and sedge communities) and/or low pollen production. High contents of reworked pollen mirror the erosion of older deposits confirming sparse vegetation cover. Other bioindicators (namely beetles, plant microfossils, and rhizopods) also point to rather sparse tundra and steppe environments in the area and harsh climates (Kuzmina, 2002; Bobrov et al., 2004; Kienast et al., 2005; Sher et al., 2005; Andreev et al., 2009).

\subsection{Middle Weichselian (Karginsky) interstadial (ca 50-30 kyr BP,} MIS 3)

Numerous and relatively well-dated Middle Weichselian records are available from the Laptev Sea region and adjacent areas (e.g. Andreev et al., 2001b, 2002a,b, 2009; Schirrmeister et al., 2002a, 2003, 2008; Wetterich et al., 2008 and references therein). The pollen spectra are characterized by the dominance of Cyperaceae and Poaceae pollen with some Artemisia and Salix in ice-rich sediments (Ice Complex deposits) dated between 50 and $40 \mathrm{kyr}$ BP, reflecting tundra-steppe environment (PZ-II of Fig. 6, PZ-I and PZ-II of Fig. 7, PZ-I of Fig. 8). Summer conditions were moister and warmer than for the Early Weichselian interval.

Higher pollen concentrations and high abundance of Poaceae, Cyperaceae, Artemisia, and Caryophyllaceae pollen, as well as permanent presence of Salix pollen, characterize the 40-32 kyr BP old sediments (PZ-II of Fig. 7, PZ-II of Fig. 8; PZ-I of Fig. 9). Open grass-sedge associations apparently dominated the area, although willow shrubs occurred possibly in more protected and wet places. Moreover, plant macrofossil studies show that remains of typical steppe and meadow plants (e.g. species from Festuca, Kobresia, Linum, Silene, and Potentilla genera) in the samples from Bykovsky Peninsula (Fig. 1, site 8) radiocarbon-dated between 48 and

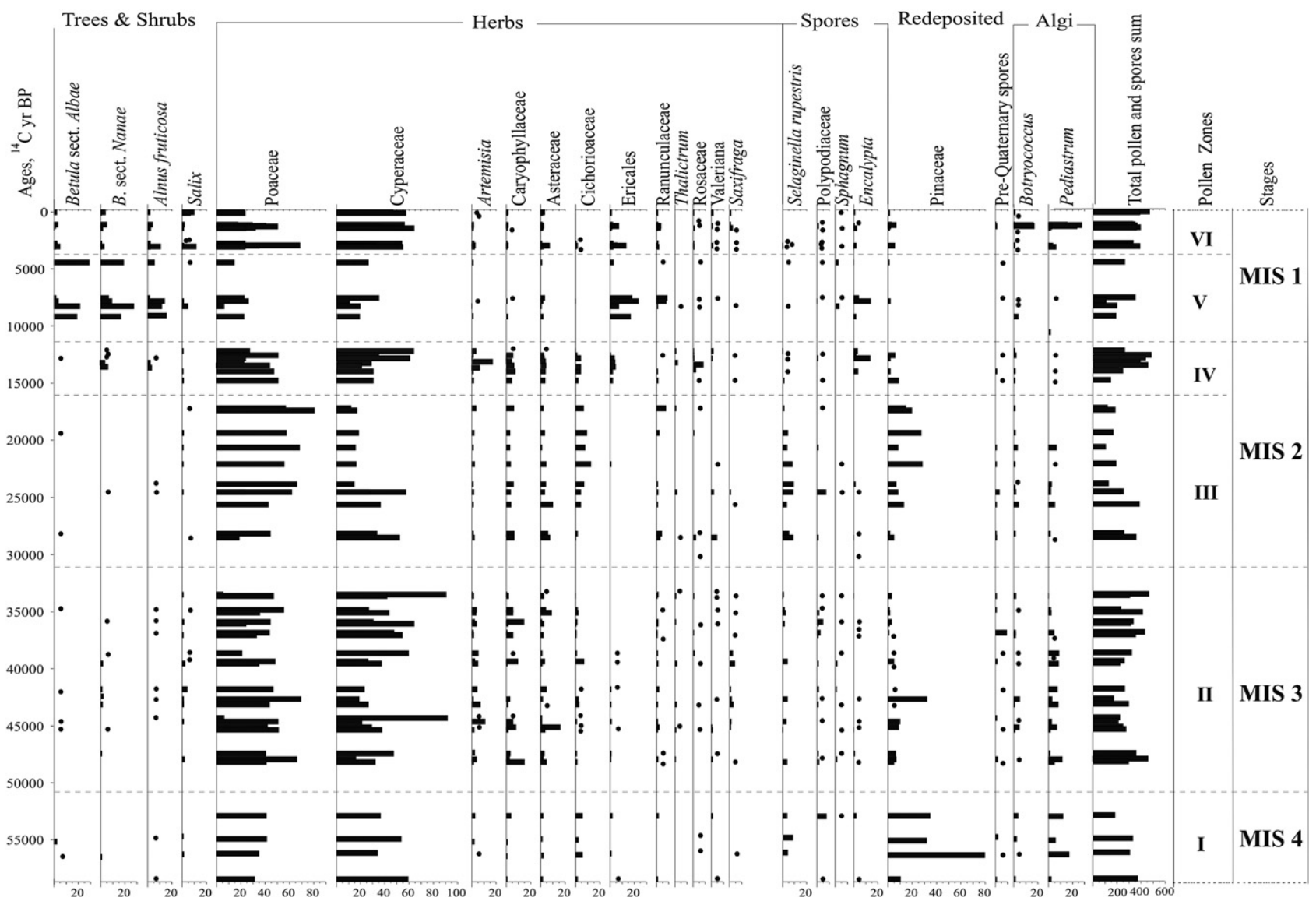

Fig. 7. Middle/Late Weichselian and Holocene simplified pollen record from Bykovsky Peninsula (site 8): pollen percentage $<1$. 


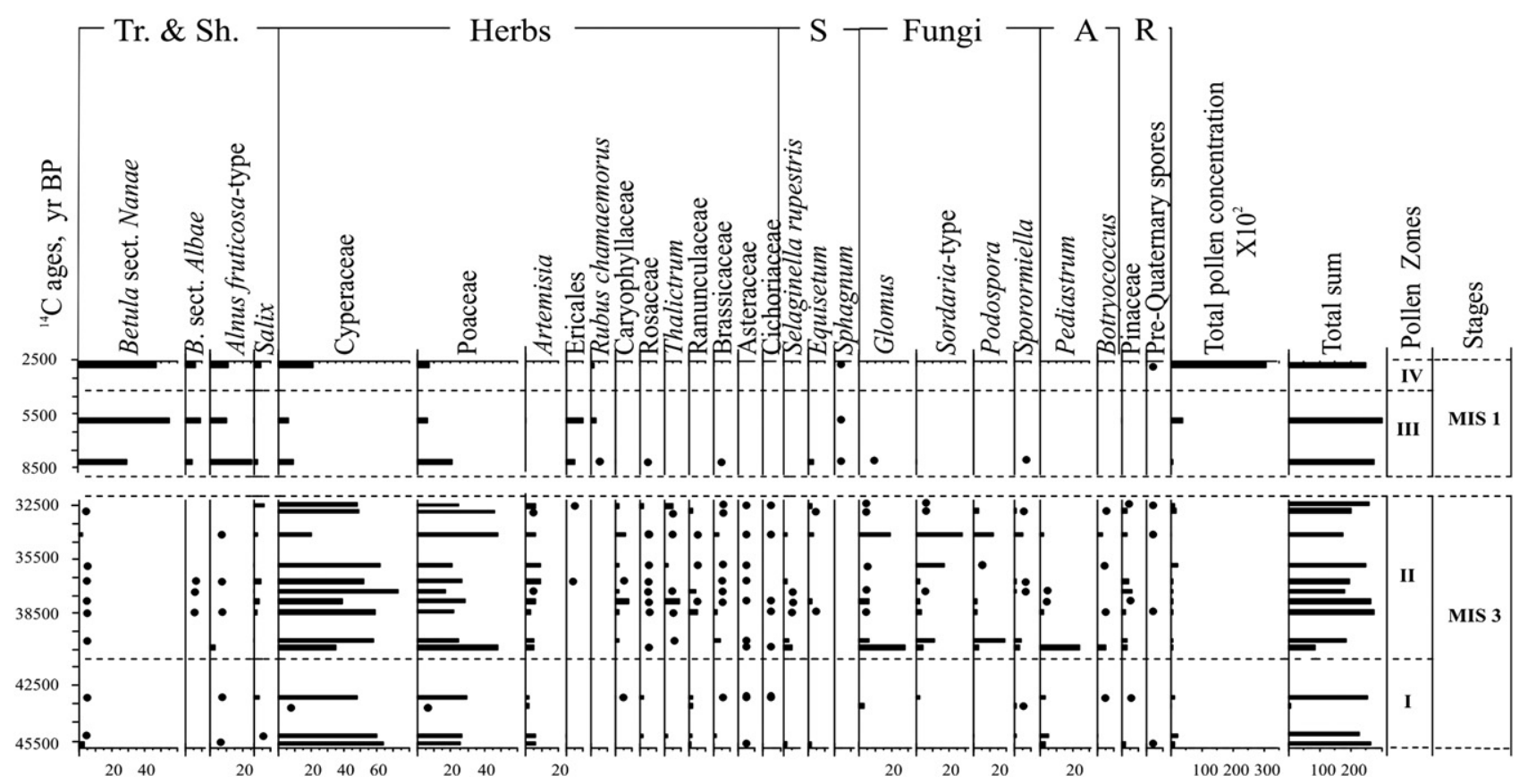

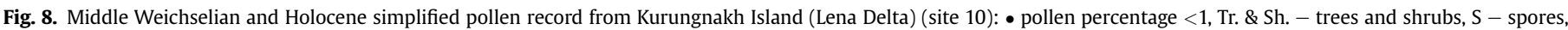
$\mathrm{R}$ - redeposited, $\mathrm{A}$ - freshwater algae.
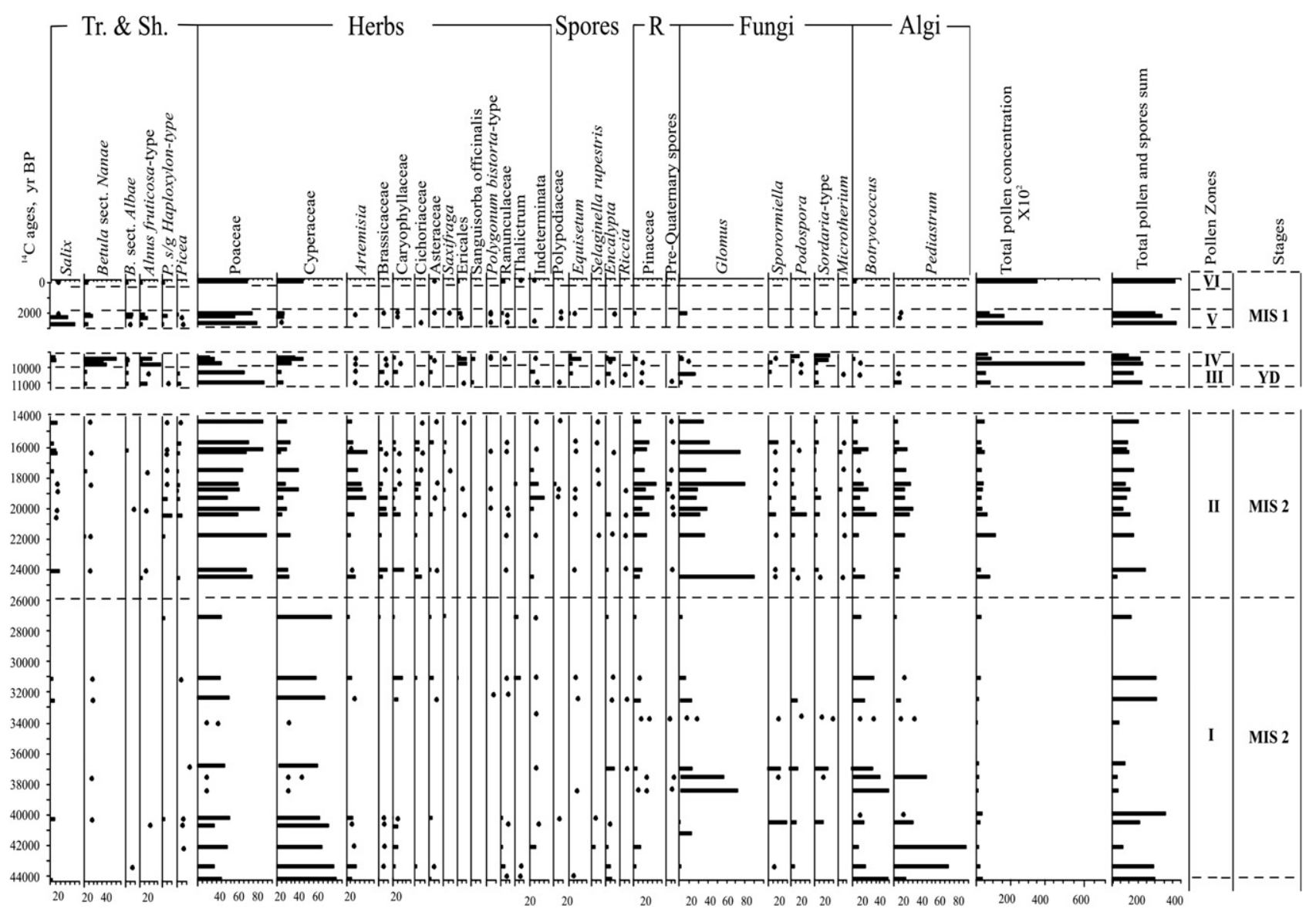

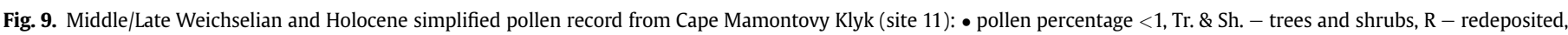
YD - Younger Dryas. 
33 kyr BP are numerous (Kienast et al., 2005). The plant macrofossils suggest relatively warm summers; for example, the occurrence of temperate Calitriche hermaphroditica is reliable evidence for mean temperature above $12{ }^{\circ} \mathrm{C}$, and the steppe taxon Thesium suggests temperatures higher than $15{ }^{\circ} \mathrm{C}$ (Kienast et al., 2005). However, single finds of such taxa may reflect extremely local microclimatic habitat variability rather than a truly regional signal.

The Middle Weichselian deposits also often contain peat lenses and peaty paleosols relatively rich in rhizopod shells of soil-eurybiotic, hydrophilic, and sphagnobiotic taxa (Andreev et al., 2002a, 2009; Schirrmeister et al., 2003; Bobrov et al., 2004, 2009; Müller et al., 2009a). Both peat accumulation and rhizopod content point to relatively wet soil environments during the Middle Weichselian interval. The frequent occurrence of green algae spores as well of freshwater ostracod shells (Wetterich et al., 2005, 2008) suggest the existence of small ponds, perhaps within ice-wedge polygons. The largest proportion of radiocarbon-dated mammal bones collected in the study region also belongs to the 44-32 kyr BP interval, reflecting numerous grazing herds during this interval (Kuznetsova et al., 2004; Sher et al., 2005; Andreev et al., 2009 and references therein). However, depauperate Middle Weichselian insect assemblages dominated by tundra taxa indicate severe environments similar to the present (Kuzmina, 2002; Sher et al., 2005; Andreev et al., 2009).

Thus, numerous bioindicators (except insects) point to some climate amelioration during the Middle Weichselian. The 40-32 kyr BP interval appears to be the regional Middle Weichselian climatic optimum. The relatively moderate interstadial at around 50-30 kyr BP is also evident at other locations in northern Siberia (e.g. Anderson and Lozhkin, 2001; Andreev et al., 2002c, 2006; Fradkina et al., 2005a; Müller et al., 2010; Fig. 1, site E and references therein).

\subsection{Late Weichselian (Sartan) stadial (ca 30-13 kyr (34.5-15.5 cal kyr) BP, MIS 2)}

Permafrost sequences from the Bykovsky Peninsula (Andreev et al., 2002b; Schirrmeister et al., 2002a; Fig. 1, site 8) and Cape Mamontovy Klyk (Schirrmeister et al., 2008; Fig. 1, site 11) outcrops provide the best radiocarbon-dated Late Weichselian pollen records (PZ-III of Fig. 7 and PZ-II of Fig. 9) from the region. Pollen assemblages mostly composed of the pollen of Poaceae, with some Cyperaceae, Artemisia, Brassicaceae and Caryophyllaceae, indicating that open tundra- and steppe-like environments existed during this stadial. Low pollen concentrations, larger amounts of Selaginella rupestris spores (indicator of very dry habitats), reworked Pinaceae pollen; and the presence of Glomus spores (indicator of disturbed soils) are also characteristic. The pollen spectra point to very cold and dry summer climates during the interval. However, relatively high abundances of green algae colonies in the studied sediments indicate their accumulation under aquatic environment (probably ponds in low-centred polygons).

The composition of insect assemblages from Bykovsky Peninsula (Fig. 1, site 8) points to summer temperatures lower-thanpresent in interval between about 25 and $18 \mathrm{kyr}$ BP (Kuzmina, 2002; Sher et al., 2005). Rhizopod records reflect extremely cold and dry soil environments during this interval (Bobrov et al., 2004). Plant macrofossil remains of taxa typical of extremely cold-resistant Kobresia meadows and Arctic pioneer communities also suggest winters colder-than-present and thin or absent snow cover during the Late Weichselian (Kienast et al., 2005). The last assumption is consistent with the Bykovsky stable isotope records of ground ice showing the lowest values of $\delta^{8} \mathrm{O}$ and $\delta \mathrm{D}$ that reflect very low winter temperatures during the Late Weichselian interval (Meyer et al., 2002b).
Similar Late Weichselian records were found in the western part of the Laptev Sea region, on the Taymyr Peninsula (Andreev et al., 2002c, 2003, Fig. 1, sites A, B, C; Kienast et al., 2001; Fig. 1, site B). However, permafrost sequences and lacustrine cores from Taymyr Peninsula show significantly higher contents of Artemisia pollen than records from eastern parts of the region (Fig. 1, sites 1-11). Generally, records show gradual decrease of Artemisia content eastwards (from the Taymyr Peninsula to the Dmitri Laptev Strait) probably reflecting corresponding changes in the local vegetation cover and more arid conditions because of stronger continentality and aridity to the east. Aridity is well reflected in the Bykovsky plant macrofossil assemblages by the presence of salt indicators, steppe plants and indicators of strong ground water fluctuations (Kienast et al., 2005).

Although all bioindicator data point to unfavorite conditions for plant growth during the Late Weichselian, vegetation was at least locally productive enough to support grazing herds and consequently human hunters (Pitulko et al., 2004). Several mammal bones radiocarbon-dated to the Late Weichselian collected at the Bykovsky Peninsula and other locations in the Laptev See region also confirm mammal fauna during this interval (Schirrmeister et al., 2002a, 2008; Kuznetsova et al., 2003, 2004; Andreev et al., 2001b, 2009; Kuznetsova and Starodubtseva, 2009) but not as rich as during the previous Middle Weichselian interstadial (Sher et al., 2005).

Sediments radiocarbon-dated to around 16.5-14.5 kyr BP (19.5-17.5 kyr cal BP) (PZ IV of Fig. 7 and the uppermost spectra of PZ II of Fig. 9) contain higher amounts of Salix and Betula pollen than the older sediments, indicating a climate amelioration after the Last Glacial Maximum (Andreev et al., 2002b; Schirrmeister et al., 2002a, 2008).

\subsection{Lateglacial transition (ca 13-10.3 kyr (15.5-12 cal kyr) BP, MIS 2)}

Lateglacial terrestrial paleoenvironmental records are rare in the Laptev Sea region because active, thermokarst-related erosion during this interval and during the early Holocene removed many of the deposits dating from this period. Such records are only occasionally preserved in thermokarst depressions. One of the best multi-proxy studied Lateglacial sediments is known from Bol'shoy Lyakhovsky Island (Andreev et al., 2009; Fig. 1, site 1). Its Allerødage pollen spectra (PZ-II of Fig. 10) are dominated mostly by Cyperaceae and Poaceae. However, the presence of Salix and Betula sect. Nanae pollen reflects that shrubs also grew in the area (birch is absent from the modern vegetation). Similar dated pollen spectra from the region are characterized by a significant increase in Salix and, especially, Betula pollen: up to $10 \%$ in Oyogos Yar (Wetterich et al., 2009; Fig. 1, site 2); up to $30 \%$ in Kotelny Island record (Makeyev et al., 2003; Fig. 1, site 3), up to $25 \%$ in Bunge Land Schirrmeister et al., 2010; Fig. 1, site 4), up to $10 \%$ in the Bykovsky Peninsula record (Andreev et al., 2002b; Schirrmeister et al., 2002a; Fig. 1, site 8); up to $60 \%$ in the Tiksi area (Grosse et al., 2007; Fig. 1, site 7), and up to 70\% in Dolgoe Lake record (Pisaric et al., 2001; Fig. 1, site 9); Generally, Allerød pollen records from the inland areas show higher shrub values, suggesting that these sites were characterized by more favourable microclimatic conditions. Thus, shrubby tundra vegetation was widespread across inland areas of the Laptev Sea region during the Allerød. The studied sediments also contain rhizopods and insect remains that point to local climate conditions more favourable than present (Andreev et al., 2009).

Pollen-based climate reconstructions show that the summer temperature reached $8-12^{\circ} \mathrm{C}$, while annual precipitation was similar to present (Andreev et al., 2009). Early summer insolation values were 


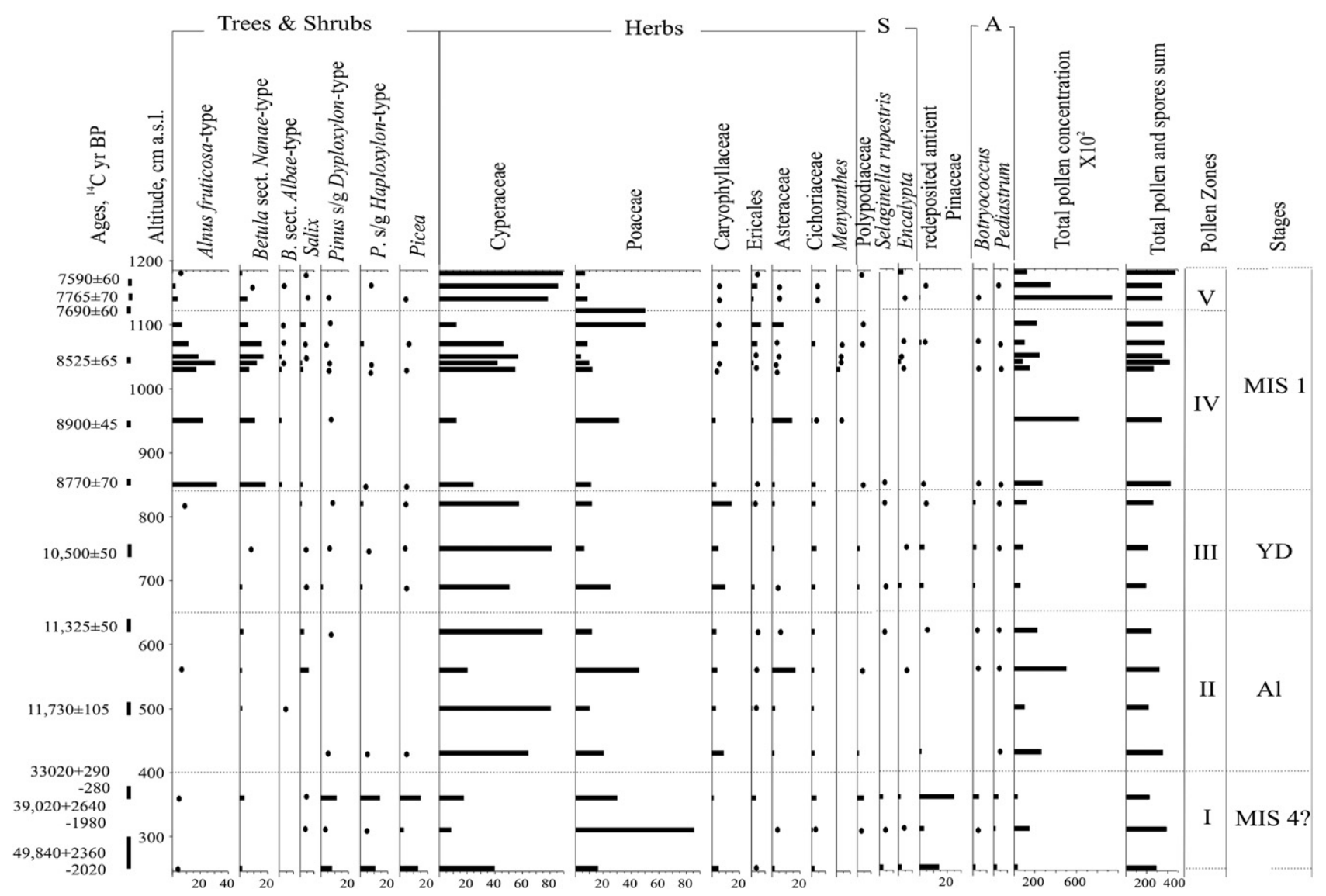

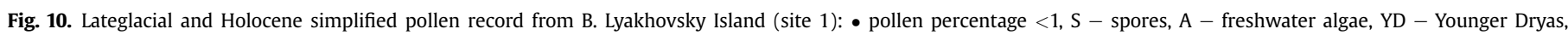
$\mathrm{Al}$ - Allerød.

high and likely generated summer warmth. Enhanced continentality due to the exposed Laptev Sea shelf (Bauch et al., 2001), more extensive sea-ice and lower sea surface temperatures would have enhanced the higher-than-present seasonality during this period.

Pollen concentration is lower in the sediments accumulated shortly before the early Holocene warming (e.g. PZ-III of Fig. 9 and PZ-III of Fig. 10). These sediments contain only single pollen grains of shrubs, whereas Brassicaceae, Caryophyllaceae, Asteraceae pollen and Glomus spore contents are high. The spectra mirror the environmental changes which can be correlated with Younger Dryas cooling. Rhizopod species diversity and abundance are also very low in the Bol'shoy Lyakhovsky Island sediments of Younger Dryas age, and soil taxa are especially indicative of unfavorable, dry and cold environments (Andreev et al., 2009).

Pollen records dated to the Younger Dryas from the inland sites to the south and southwest (Pisaric et al., 2001; Grosse et al., 2007; Wetterich et al., 2009) demonstrate drastic decreases of shrub and tree pollen in comparison with the Allerød sediments. Although the pollen data of Younger Dryas age from the western and eastern parts of Beringia are somewhat equivocal as regards a climatic reversal (e.g. Kokorowski et al., 2008; Meyer et al., 2010 and references therein), the Laptev Sea environmental records point to a Younger Dryas reversal.

\subsection{Holocene (10.3 kyr-0 BP (12-0 cal kyr) BP, MIS 1)}

Early Holocene pollen records are numerous in the study region (Andreev et al., 2001a, 2002b, 2003, 2004b, 2009; Pisaric et al., 2001; Schirrmeister et al., 2002a, 2003, 2008; Makeyev et al., 2003; Wetterich et al., 2009 and references therein). Pollen spectra are dominated mostly by shrubs (Alnus fruticosa, Betula nana and Salix) and semi-shrubs (Ericales), with some Cyperaceae and Poaceae (the uppermost pollen zones of Figs. 7-10). Spores of Equisetum and Encalypta, indicators of disturbed soils, are also common in early Holocene sediments. The records indicate that shrub-tundra vegetation was dominant in the study region between 10-7.6 (11.5-8.4 cal) kyr BP. Pollen-based climate reconstruction from the regional pollen records inferred a temperature up to $4^{\circ} \mathrm{C}$ higher than present (Andreev et al., 2002a,b,c, 2003, 2004b, 2008).

Other bioindicator records also reflect significant climate amelioration during the early Holocene. Beetle remains found in the sediments point to a mosaic landscape under warm climate (Kuzmina and Sher, 2006; Andreev et al., 2009). All ecological groups of rhizopods found in the sediments also reflect more developed soil environments compared with Late Weichselian ones, when only a few soil and eurybiotic species were present (Andreev et al., 2002b, 2003, 2004b, 2009; Bobrov et al., 2004, 2009; Müller et al., 2009a).

After 7.6 (8.4 cal) kyr BP shrub vegetation gradually disappeared from the modern high Arctic and Arctic tundra areas in the Laptev Sea region (Andreev et al., 2002b,c, 2003, 2004b, 2008, 2009; Schirrmeister et al., 2008; Wetterich et al., 2008, 2009 and references therein). Vegetation cover became similar to modern tundra during the middle and late Holocene.

Rhizopod diversity is significantly lower in sediments accumulated after ca $7.5 \mathrm{kyr}$ BP (for example, many sphagnophilic and hydrophilic taxa disappeared), which also points to a deterioration of conditions. We suggest that this may be connected with marine transgression on to the exposed Laptev Sea shelf during the Middle Holocene (Bauch et al., 2001). However, pollen records from the 
Age [kyr]

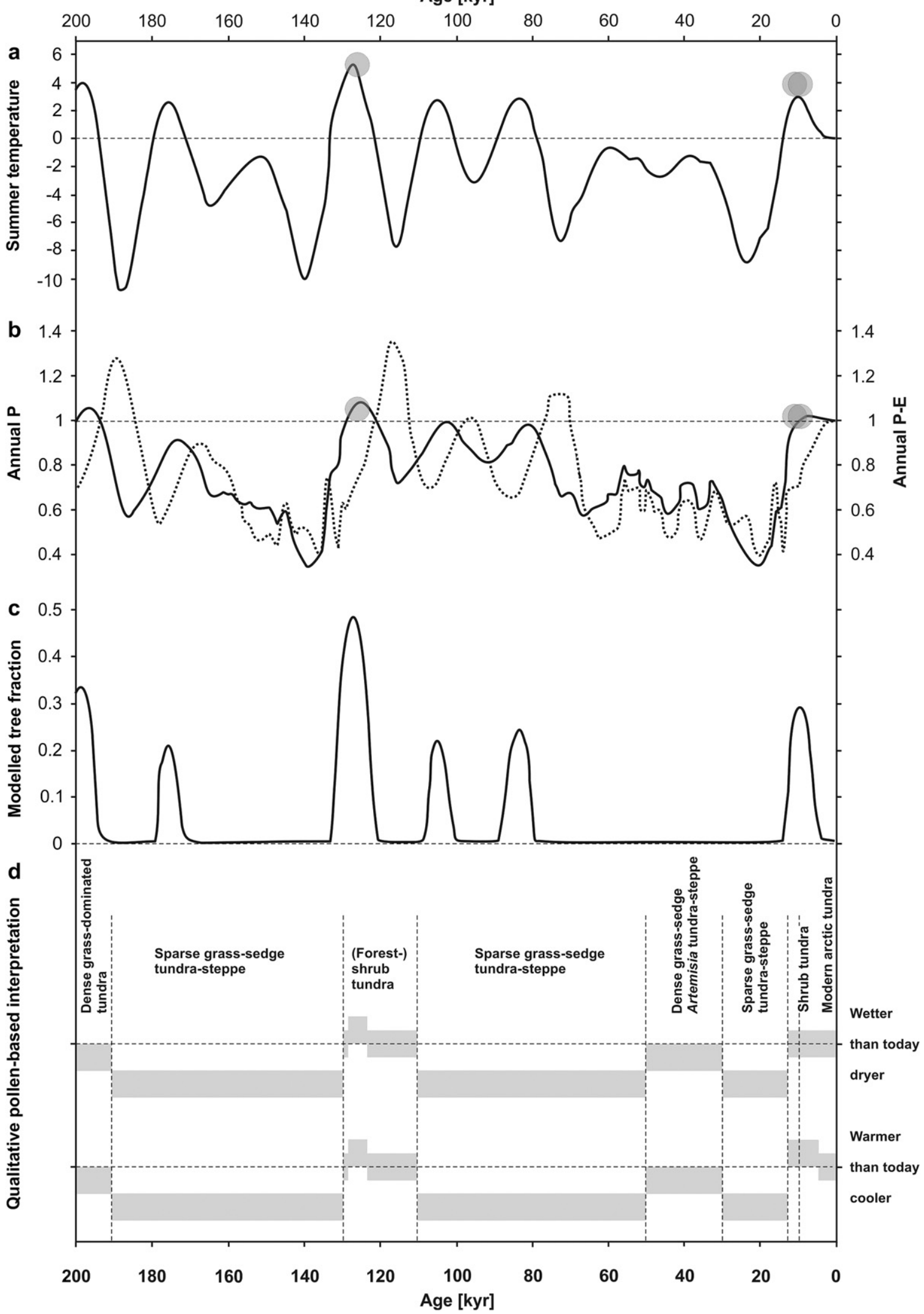

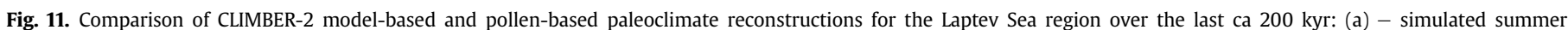

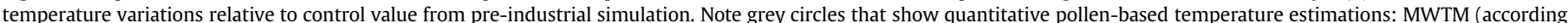

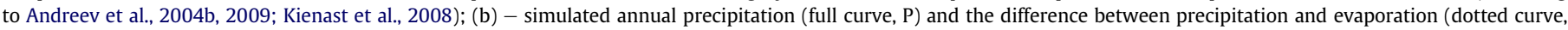

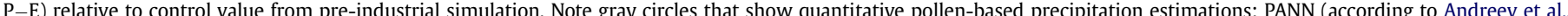

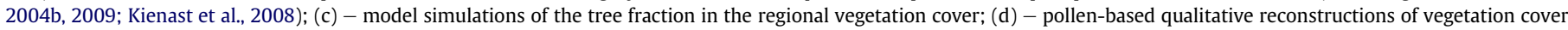
are presented as descriptions of dominant vegetation type and in comparison to modern conditions shown as gray bars. 
more continental areas (e.g. Central Yakutia, Andreev et al., 2002a, 2005; Andreev and Klimanov, 2005; Müller et al., 2009b, 2010 and references therein) show that climate conditions showed little deterioration until the late Holocene, ca $2.5 \mathrm{kyr}$ BP.

The few extant late-Holocene pollen records from Laptev Sea coastal regions have high values (up to 20-30\%) of Betula nana pollen in spectra radiocarbon-dated to 3.7 and $3.3 \mathrm{kyr} \mathrm{BP}$, indicating that dwarf birch grew then in areas where it does not grow today (Andreev et al., 2009 and references therein). Thus, pollen records indicate a slightly warmer-than-present climate until at least this time, after which environmental conditions became similar to present (Andreev et al., 2001a, 2004b; Pisaric et al., 2001).

\section{Comparison of paleoenvironmental data vs. model data}

We compare here simulations performed with the Earth system model of intermediate complexity, CLIMBER-2, with the paleoclimate and paleoenvironmental reconstructions described above for the Laptev Sea region over the past 200 kyr. We discuss selected climate intervals available from this simulation for northern Siberia and compare them to the bioindicator-based (mostly pollen data) reconstructions in order to estimate how well regional paleodata and model simulations match each other. An aim is to assess how well the model performs in simulating radically different climates by comparing it with geological data, as well as to evaluate to what degree the bioindicator-based reconstructions could be understood within the framework of a mechanistic climate model.
To compare paleodata with results of model simulations we used the model output from the grid cell which covers the Laptev Sea region. Model output is represented as time series of summer (June, July, August, JJA) temperature, precipitation, and $\mathrm{P}-\mathrm{E}$ (precipitation minus evaporation) anomalies, plus simulated fractions of tree cover, and paleoclimatic and paleoecological interpretations for different periods represented in the time series are displayed as appropriate (see Fig. 11).

Simulated summer temperature variations in northern Siberia closely follow local summer insolation with strong processional periodicity (Fig. 11a). Effects of greenhouse gases variations are evident but more pronounced in annual and winter temperatures (not shown in Fig. 11). The simulated summer temperature is $5^{\circ} \mathrm{C}$ and $3{ }^{\circ} \mathrm{C}$ higher than present during the Eemian Interglacial and early Holocene, respectively, which is in good agreement with the pollen-based reconstructions. At the same time, pollen records do not support simulated warm intervals corresponding to MIS $5 \mathrm{c}$ and MIS 5a. Simulated summer temperature during the last glacial maximum was $8{ }^{\circ} \mathrm{C}$ below present and even lower during the penultimate glaciation.

Fig. 11b shows two simulated variables related to the hydrological conditions: the annual precipitation $(\mathrm{P})$ and the difference between precipitation and evaporation $(\mathrm{P}-\mathrm{E})$; both variables are normalized by their pre-industrial values. In the paleoclimatological literature, "wetter" conditions are often associated with "more rain" and "dry" conditions with "less rain". However, precipitation changes are usually accompanied by significant temperature changes. The latter strongly affect evaporation and therefore soil moisture. Since

Table 2

Vegetation and climate changes in the Laptev Sea region during the last ca $200 \mathrm{kyr}$

\begin{tabular}{|c|c|c|}
\hline Stages (MIS, age kyr BP) & Pollen assemblages & Palaeoenvironments \\
\hline $\begin{array}{l}\text { Late Holocene } \\
\quad\left(\text { MIS } 1,<5{ }^{14} \mathrm{C} \text { kyr BP }\right)\end{array}$ & $\begin{array}{l}\text { Grass dominated spectra, rare } \\
\text { Betula nana pollen }\end{array}$ & $\begin{array}{l}\text { Grass tundra similar to modern, dwarf birches in more protected } \\
\text { places and temperatures slightly warmer than today until ca } 3.3 \mathrm{kyr} \text { BP }\end{array}$ \\
\hline $\begin{array}{l}\text { Early/middle Holocene } \\
\quad \text { (MIS 1, ca 10.3-5 kyr BP) }\end{array}$ & $\begin{array}{l}\text { Spectra dominated by shrub pollen, } \\
\text { high pollen concentration }\end{array}$ & $\begin{array}{l}\text { Shrub tundra in the modern Arctic tundra areas; after c. } 7.7-7.5 \mathrm{kyr} \text { BP } \\
\text { shrubs gradually disappeared from modern coastal regions; summer } \\
\text { temperature were at least } 4^{\circ} \mathrm{C} \text { higher than today (pollen-based) and the } \\
\text { precipitation was also higher than modern }\end{array}$ \\
\hline Younger Dryas & Grass-sedge dominated spectra, low & Open tundra and steppe like habitats, climate deterioration \\
\hline
\end{tabular}

(ca $11-10.3{ }^{14} \mathrm{C}$ kyr BP)

Allerød

(ca 13-11 kyr BP)

Late Weichselian

(MIS 2, ca 30-13 kyr BP)

Middle Weichselian Interstadial

(MIS 3, ca 50-30 kyr BP)

Early Weichselian Stadial

(MIS 4, ca 110-50 kyr

Eemian Interglacial

(MIS 5e, ca 130-110 kyr)

Pre-Eemian Stadial

(MIS 6?, 190 to $130 \mathrm{kyr}$ )

Late Saalian interstadial

(MIS 7a?, ca 200 to $190 \mathrm{kyr}$ )

Late Saalian stadial period

MIS 7b?, >200 kyr pollen concentrations

Mostly grass and sedge; presence of

Salix and Betula sect. Nanae

Mostly grass with some

Cyperaceae, Artemisia

Grass, sedge and Caryophyllaceae dominated spectra with few Salix, relatively high pollen concentration Grass-sedges dominated with few other herbs, low pollen concentration

Grass-sedge dominated, few other herbs, low pollen concentration, rare Alnus and Betula pollen

Shrub (alder, birch, and willow

dominated spectra, high

pollen concentration.

Grass and Artemisia dominated

spectra, presence of Alnus fruticosa,

Salix, Betula nana pollen

Grass-sedge with some other herbs, high

values of green algae colonies, very low

pollen concentration, large amounts

of reworked conifers

Grass dominated spectra with few sedges,

high pollen concentration

Grass-sedge dominated spectra with few

Asteraceae and Cichoriaceae, low pollen

concentration, large amounts

of reworked conifers
Grass-sedge dominated habitats, shrubs in protected places, summer temperature were up to $4{ }^{\circ} \mathrm{C}$ higher than today,

precipitation similar to present

Open tundra- and steppe-like environments, very cold and dry climate

Open herb dominated vegetation, shrub willow stands in more protected places, climate warmer and moister than during previous stage

Grass-sedge dominated vegetation; disturbed soils and erosion, severe climate sparse grass-sedge vegetation, occasional deep lakes, harsh climate conditions

Grass-sedge dominated tundra habitats but, probably, with some shrubs in more protected places; climate similar to present or slightly warmer

Shrub tundra, warm climate (summer temperatures $4-5^{\circ} \mathrm{C}$ higher them modern)

Open grass and Artemisia dominated vegetation but shrubs present; relatively warm temperatures compared with previous stage

Disturbed soils and erosion, sparse grass-sedge dominated vegetation, cold and dry climate

Dense grass dominated tundra, rather warm and wet summer, but cold winter

Sparse grass-sedge dominated vegetation,

disturbed soils, severe climate 
vegetation cover is partly controlled by the availability of soil moisture, $\mathrm{P}-\mathrm{E}$ values are a useful indicator of hydrological changes that may affect vegetation. As it is shown in Fig. 11b, temporal evolution of $\mathrm{P}$ and $\mathrm{P}-\mathrm{E}$ are not identical. While during the coldest periods both variables indicate "drier" conditions (which is in good agreement with proxy-based climate reconstructions), during warm periods they are out of phase; this is probably because periods of high summer insolation drive an increase in evaporation rates that can exceed increases in precipitation, and thus changes in $\mathrm{P}$ and $\mathrm{P}-\mathrm{E}$ have different signs. It is interesting that proxy-based $\mathrm{P}$ reconstructions during warm periods are more consistent with the simulated $\mathrm{P}$ changes rather than the $\mathrm{P}-\mathrm{E}$ changes. This may imply that in the study region precipitation is a more important influence than $\mathrm{P}-\mathrm{E}$, or alternatively and more likely, it may reflect that in high latitudes it is difficult to separate the effects of temperature and precipitation changes on vegetation cover as they tend to vary in synchrony.

The model simulates a considerable increase in the tree fraction during interglacials and MIS $5 \mathrm{c}$ and $5 \mathrm{a}$ (Fig. 11c). The simulated tree fractions for the interglacial period agree with pollen records indicating appearance of shrubs and trees in the study area. This is also in line with the previous CLIMBER-2 simulations that showed an increase in tree fraction at the Arctic region of Northern Eurasia for the Eemian (Kubatzki et al., 2000) and the Holocene (Brovkin et al., 2002). These changes in high-latitude tree cover profoundly amplify of high-latitude warming through the snow-masking effect of forests (Ganopolski et al., 1998; Brovkin et al., 2003). The existing Laptev Sea pollen and plant macrofossil records do not support the modeled tree fraction maxima during interstadial conditions of MIS $5 \mathrm{c}$ and MIS 5a. Possible explanations of the paleodata/model mismatches might be that palaeo records dated to MIS $5 \mathrm{c}$ and $5 \mathrm{a}$ are fragmented due to erosion processes removing some stratigraphic units. Such stratigraphic hiatuses are well documented for the radiocarbon-dated Late Pleistocene (MIS 3 and MIS 2) and Holocene (MIS 1) sediments in the study region (e.g. Schirrmeister et al., 2003; Wetterich et al., 2008; Andreev et al., 2002b, 2009). Moreover, a continuous lacustrine record from El'gygytgyn Lake in Chukotka to the east (Lozhkin et al., 2007; Matrosova, 2009) shows peaks in tree and shrub pollen that may correspond to the MIS $5 \mathrm{c}$ and/or 5a intervals. However, other possible explanations lie with the model: changes in the distance to the ocean are neglected because of its coarse spatial resolution, and it does not take into account changes in active-layer depth or the physiological effect of reduced $\mathrm{CO}_{2}$ levels.

\section{Conclusions}

The vegetation dynamics of the Middle and Late Quaternary of the non-glaciated part of the northeast Siberia during the last $200 \mathrm{kyr}$ reflect a series of changes that include several stadial and interstadial intervals and the last interglaciation and Holocene periods (Table 2). Reconstructed environmental changes fit well with global glacial-interglacial and stadial-interstadial cycles and other regional paleoenvironmental records (e.g., Fradkina et al., 2005a, b; Lozhkin et al., 2007 and references therein). The regional proxy-based paleoenvironmental and paleoclimatic reconstructions compare well with simulations performed with a model of intermediate complexity, CLIMBER-2, although some differences are evident, especially concerning MIS $5 c$ and $5 a$. Further investigations of new sequences and the application of new geochronological methods with longer age ranges and higher dating precision will help to extend and complete the existing paleoenvironmental record. The development of earth system models of higher complexity, and particularly their modification to include critical elements related to Arctic environments, such as permafrost, should improve upon existing simulations.

\section{Acknowledgements}

This research is a contribution to the German Science Foundation (DFG) supported projects “Late Quaternary environmental history of interstadial and interglacial periods in the Arctic reconstructed from bioindicators in permafrost sequences in NE Siberia" (SCHI 975/1-2, RI 809/17) and "Comparison of climate and carbon cycle dynamics during Late Quaternary interglacials using a spectrum of climate system models, ice-core and terrestrial archives" (TA 540/1-2, BR 2950/2-2). We thank many student assistants for preparing the numerous pollen samples during the last 11 years. The valuable comments and suggestions of two anonymous reviewers for the first version of the manuscript are greatly acknowledged. Special thanks also go to Prof. Mary Edwards (University of Southampton) for valuable scientific comments and suggestions.

\section{Supplementary data}

Supplementary data related to this article can be found online at doi:10.1016/j.quascirev.2010.12.026.

\section{References}

ACIA, 2005. Impacts of a Warming Arctic: Arctic Climate Impact Assessment. Cambridge University Press, Cambridge.

ACIS, 2008. ACIS - Arctic Climate Impact Science - an Update since ACIA. WWF International Arctic Program (Oslo, Norway).

Anderson, P.M., Lozhkin, A.V., 2001. The stage 3 interstadial complex (Karginskii/ middle Wisconsinan interval) of Beringia: variations in paleoenvironments and implications for paleoclimatic interpretations. Quaternary Science Reviews 20, 93-125.

Andreev, A.A., Klimanov, V.A., Sulerzhitsky, L.D., 2001a. Vegetation and climate history of the Yana River lowland during the last 6400 yr. Quaternary Science Reviews 20, 259-266.

Andreev, A.A., Peteet, D.M., Tarasov, P.E., Filimonova, L., Romanenko, F.A., Sulerzhitsky, L.D., 2001b. Late Pleistocene interstadial environment on Fadeyevsky Island, east-Siberian Sea, Russia. Arctic, Antarctic, and Alpine Research 33, 28-35.

Andreev, A.A., Klimanov, V.A., Sulerzhitsky, L.D., 2002a. Vegetation and climate history of central Yakutia during the Holocene and late Pleistocene. Botanicheskiy Zhurnal 87, 86-98 (in Russian).

Andreev, A.A., Schirrmeister, L., Siegert, Ch., Bobrov, A.A., Demske, D., Seiffert, M., Hubberten, H.-W., 2002b. Paleoenvironmental changes in northeastern Siberia during the Upper Quaternary - evidence from pollen records of the Bykovsky Peninsula. Polarforschung 70, 13-25.

Andreev, A.A., Siegert, C., Klimanov, V.A., Derevyagin, A.Yu., Shilova, G.N., Melles, M., 2002c. Late Pleistocene and Holocene vegetation and climate changes in the Taymyr lowland, Northern Siberia reconstructed from pollen records. Quaternary Research 57, 138-150.

Andreev, A.A., Tarasov, P.E., Siegert, Ch., Ebel, T., Klimanov, V.A., Bobrov, A.A., Melles, M., Derevyagin, A.Yu., Hubberten, H.-W., 2003. Vegetation and climate changes on the northern Taymyr, Russia during the Upper Pleistocene and Holocene reconstructed from pollen records. Boreas 32, 484-505.

Andreev, A.A., Grosse, G., Schirrmeister, L., Kuzmina, S.A., Novenko, E.Yu., Bobrov, A.A., Tarasov, P.E., Kuznetsova, T.V., Krbetschek, M., Meyer, H., Kunitsky, V.V., 2004a. Late Saalian and Eemian palaeoenvironmental history of the Bol'shoy Lyakhovsky Island (Laptev Sea region, Arctic Siberia). Boreas 33, 319-348.

Andreev, A.A., Tarasov, P.E., Schwamborn, G., Ilyashuk, B.P., Ilyashuk, E.A., Bobrov, A.A., Klimanov, V.A., Rachold, V., Hubberten, H.-W., 2004b. Multi-proxy Holocene paleoenvironmental records from Nikolay Lake, Lena River Delta, Arctic Russia. Palaeogeography, Palaeoclimatology, Palaeoecology 209, 197-217.

Andreev, A.A., Klimanov, V.A., 2005. Lateglacial and Holocene in east Siberia (based on data obtained mainly in central Yakutia). In: Velichko, A.A., Nechaev, V.P. (Eds.), Cenozoic Climatic and Environmental Changes in Russia Geological Society of America Bulletin 382, pp. 98-102.

Andreev, A.A., Forman, S.L., Ingólfsson, O., Manley, W.F., 2006. Middle Weichselian environments on western Yamal Peninsula, Kara Sea based on pollen records. Quaternary Research 65, 275-281.

Andreev, A.A., Tarasov, P.E., 2007. Pollen records, postglacial: northern Asia. In: Elias, S.A. (Ed.), Encyclopedia of Quaternary Science, vol. 4. Elsevier, Amsterdam, Netherlands, pp. 2721-2729.

Andreev, A.A., Grosse, G., Schirrmeister, L., Kuzmina, S.A., Kuznetsova, T.V., Bobrov, A.A., Tarasov, P.E., Novenko, E.Yu., Meyer, H., Kienast, F., Bryantseva, A., Derevyagin, A.Yu., Kunitsky, V.V., 2009. Weichselian and Holocene 
palaeoenvironmental history of the Bol'shoy Lyakhovsky Island, New Siberian Archipelago, Arctic Siberia. Boreas 38, 72-110.

Arkhipov, S.A., Volkova, V.S., Zolkina, V.S., Krutkover, A.A., Kul'kova, L.A., 2005. West Siberia. In: Velichko, A.A., Nechaev, V.P. (Eds.), Cenozoic Climatic and Environmental Changes in Russia. Geological Society of America Special Paper 382, pp. $105-120$.

Astakhov, V.I., 2001. The stratigraphic framework for the Upper Pleistocene of the glaciated Russian Arctic: changing paradigms. Global and Planetary Change 31 283-295.

Astakhov, V.I., 2004. Middle Pleistocene glaciations of the Russian north. Quaternary Science Reviews 23, 1285-1311.

Astakhov, V.I., 2006. Chronostratigraphic subdivisions of the Siberian upper Pleistocene. Russian Geology and Geophysics 47, 1207-1220.

Astakhov, V.I., Mangerud, J., 2005. The age of the Karginsky Interglacial Strata on the lower Yenissei. Doklady Earth Sciences 403, 673-676.

Atlas Arktiki, 1985. GUGK, Moscow (in Russian).

Barkova, M.B., 1990. Spore-pollen complexes of the Middle Pleistocene of YanaKolyma region and their significance for stratigraphy and correlation of sediments. In: Shulgina, N.I. (Ed.), Stratigrafiya i paleontologiya mezo-kaynozoya Sovetskoi Arktiki. PGO "Sevmorgeologiya", Ministry of Geology, Leningrad, pp. 113-127 (in Russian).

Bauch, H.A., Mueller-Lupp, T., Taldenkova, E., Spielhagen, R.F., Kassens, H., Grootes, P.M., Thiede, J., Heinemeier, J., Petryashov, V.V., 2001. Chronology of the Holocene transgression at north Siberian margin. Global and Planetary Change 31, 125-139.

Bauer, E., Ganopolski, A, 2010. Aeolian dust modeling over the past four glacial cycles with CLIMBER-2. Global and Planetary Change 74, 49-60. doi:10.1016/ j.gloplacha.2010.07.009.

Berglund, B.E., Ralska-Jasiewiczowa, M., 1986. Pollen analysis and pollen diagrams. In: Berglund, B.E. (Ed.), Handbook of Holocene Palaeoecology and Palaeohydrology. Interscience, New York, pp. 455-484.

Berger, A., 1978. Long-term variations of daily insolation and Quaternary climatic changes. Journal of Atmospheric Science 35, 2362-2367.

Beug, H.-J., 2004. Leitfaden der Pollenbestimmung für Mitteleuropa und angrenzende Gebiete. Verlag Dr Friedrich Pfeil, München.

Bobrov, A.A., Andreev, A.A., Schirrmeister, L., Siegert, Ch, 2004. Testate amoebae (Protozoa: Testacea) as bioindicators in the late Quaternary deposits of the Bykovsky Peninsula, Laptev Sea, Russia. Palaeogeography, Palaeoclimatology, Palaeoecology 209, 165-181.

Bobrov, A.A., Müller, S., Chizhikova, N.A., Schirrmeister, L., Andreev, A.A., 2009. Testate amoebae in late Quaternary sediments of the Cape Mamontovy Klyk (Yakutia). Biology Bulletin 36, 363-372.

Bobrov, A.E., Kupriyanova, L.A., Litvintseva, M.V., Tarasevich, V.F., 1983. Spores and Pollen of Gymnosperms from the Flora of the European Part of the USSR. Nauka, Leningrad (in Russian).

Brovkin, V., Ganopolski, A., Svirezhev, Y., 1997. A continuous climate - vegetation classification for use in climate - biosphere studies. Ecological Modelling 101, 251-261.

Brovkin, V., Bendtsen, J., Claussen, M., Ganopolski, A., Kubatzki, C., Petoukhov, V., Andreev, A., 2002. Carbon cycle, vegetation and climate dynamics in the Holocene: experiments with the CLIMBER-2 model. Global Biogeochemical Cycles 16, 1139. doi:10.1029/2001GB001662.

Brovkin, V., Levis, S., Loutre, M.-F., Crucifix, M., Claussen, M., Ganopolski, A., Kubatzki, C., Petoukhov, V., 2003. Stability analysis of the climate-vegetation system in the northern high latitudes. Climatic Change 57, 119-138.

Calov, R., Ganopolski, A., Claussen, M., Petoukhov, V., Greve, R., 2005. Transient simulation of the last glacial inception with an atmosphere-ocean-vegetationice sheet. Part I: glacial inception as a bifurcation of the climate system. Climate Dynamics 24, 545-561.

CAVM Team, 2003. Circumpolar Arctic Vegetation Map, Scale 1:7.500.000. Conservation of Arctic Flora and Fauna (CAFF) Map No.1. U.S. Fish and Wildlife Service, Anchorage, Alaska. http://www.geobotany.uaf.edu/cavm/finalcavm/index.html.

Fradkina, A.F., Alekseev, M.N., Andreev, A.A., Klimanov, V.A., 2005a. East Siberia. In: Velichko, A.A., Nechaev, V.P. (Eds.), Cenozoic Climatic and Environmental Changes in Russia. The Geological Society of America Special Paper 382, pp. 89-103.

Fradkina, A.F., Grinenko, O.V., Laukhin, S.A., Nechaev, V.P., Andreev, A.A., Klimanov, V.A., 2005b. North-eastern Asia. In: Velichko, A.A., Nechaev, V.P. (Eds.), Cenozoic Climatic and Environmental Changes in Russia. The Geological Society of America Special Paper 382, pp. 105-120.

Ganopolski, A., 2005. CLIMBER-2: an Earth system model of intermediate complexity. In: Bronstert, A., Carrera, J., Kabat, P., Lütkemeier, S. (Eds.), Coupled Models of the Hydrological Cycle. Springer, Berlin, pp. 264-268

Ganopolski, A., Kubatzki, C., Claussen, M., Brovkin, V., Petoukhov, V., 1998. The influence of vegetation-atmosphere-ocean interaction on climate during the mid-Holocene. Science 280, 1916-1919.

Ganopolski, A., Calov, R., Claussen, M., 2010. Simulation of the last glacial cycle with a coupled climate ice-sheet model of intermediate complexity. Climate of the Past 6, 229-244.

Geocryological Map of the USSR, 1996. 1:2,500,000. Moscow State University.

Gibbard, P., Cohen, K.M., 2008. Global chronostratigraphical correlation table for the last 2.7 million years. Episodes 31, 243-247.

Giterman, R.E., Sher, A.V., Matthew Jr., J.V., 1982. Comparison of the developments of tundra-steppe environment in west and east Beringia: pollen and macrofossil evidence from key sections. In: Hopkins, D.M., MatthewsJr., J.V.,
Schwerger, C.E., Young, S.B. (Eds.), Paleoecology of Beringia. Academy Press, NY, London, pp. 43-73.

Greve, R., 1997. A Continuum-mechanical Formulation for Shallow Polyhedral Ice Sheets. In: Philosophical Transactions of the Royal Society of London, Series A 355 921-974.

Grosse, G., Schirrmeister, L., Siegert, Ch., Kunitsky, V.V., Sligo, E.A., Andreev, A.A., Derevyagin, A.Y., 2007. Geological and geomorphologic evolution of a sedimentary periglacial landscape in Northeast Siberia during the Late Quaternary. Geomorphology 86, 25-51.

ICS, 2010. INQUA Subcommission on Quaternary Stratigraphy. http://www. quaternary.stratigraphy.org.uk/charts/.

Ilyashuk, B.P., Andreev, A.A., Bobrov, A.A., Tumskoy, V.E., Ilyashuk, E.A., 2006 Interglacial history of a palaeo-lake and regional environment: a multi-proxy study of a permafrost deposit from Bol'shoy Lyakhovsky Island, Arctic Siberia. Journal of Paleolimnology 35, 855-872.

Ivanov, O.A., 1972. Stratigraphy and correlation of Neogene and Quaternary deposits of subarctic plains in Eastern Yakutia. In: Problemy izucheniya chetvertichnogo perioda. Nauka, Moscow, pp. 202-211 (in Russian).

Kaplan, J.O., Bigelow, N.H., Prentice, I.C., Harrison, S.P., Bartlein, P.J., Christensen, T.R. Cramer, W., Matveyeva, N.V., McGuire, A.D., Murray, D.F., Razzhivin, V.Y. Smith, B., Walker, D.A., Anderson, P.M., Andreev, A.A., Brubaker, L.B., Edwards, M.E., Lozhkin, A.V., 2003. Climate change and Arctic ecosystems II: Modeling, paleodata-model comparisons, and future projections. Journal of Geophysical Research 108 (D19), 8171.

Kaplan, J.O., 2001. Geophysical applications of vegetation modelling. PhD Thesis, Lund University.

Kaplina, T.N., 1981. History of frozen ground in northern Yakutia during the late Cenozoic. In: Baulin, V.V., Dubikov, I. (Eds.), Istoriya razvitiya mnogoletnemerzlykh porod Evrazii. Nauka Press, Moscow, pp. 153-181 (in Russian).

Kaplina, T.N., 1989. Stages of formation of geocryological conditions. In: Yershov, E.D. (Ed.), Geokriologiya SSSR. Vostochnaya Sibir' i Dal'nii Vostok. Nedra, Moscow, pp. 20-25 (in Russian).

Kaplina, T.N., Lozhkin, A.V., 1984. Age and history of accumulation of the "Ice Complex" of the maritime lowlands of Yakutia. In: Velichko, A.A. Wright Jr., H.E., Barnosky, C.W. (Eds.), Late Quaternary Environments of the Soviet Union. University of Minnesota Press, Minneapolis, MN, pp. 147-151.

Kienast, F., Siegert, C., Dereviagin, A., Mai, D.H., 2001. Climatic implications of late Quaternary plant macrofossil assemblages from the Taymyr Peninsula, Siberia. Global and Planetary Change 31, 265-281.

Kienast, F., Schirrmeister, L., Siegert, C., Tarasov, P., 2005. Palaeobotanical evidence for warm summers in the East Siberian Arctic during the last cold stage. Quaternary Research 63, 283-300.

Kienast, F., Schirrmeister, L., Tarasov, P., Grosse, G., Andreev, A.A., 2008. Continental climate in the East Siberian Arctic during the Last Interglacial: implications from palaeobotanical records. Global and Planetary Change 60, 535-562.

Kienast, F., Wetterich, S., Kuzmina, S., Schirrmeister, L., Andreev, A.A., Tarasov, P., Nazarova, L., Kossler, A., Frolova, L., Kunitsky V.V. Boreal woodland under dry inland climate at today's Arctic coast in western Beringia during the Last Interglacial. Quaternary Science Reviews. in press, doi:10.1016/j.quascirev.2010. 11.024.

Kokorowski, H.D., Anderson, P.M., Sletten, R.S., Lozhkin, A.V., Brown, T.A., 2008 Lateglacial and early Holocene climatic changes based on a multiproxy lacustrine sediment records from Northeast Siberia. Arctic, Antarctic and Alpine Research 40, 497-505.

Kubatzki, C., Montoya, M., Rahmstorf, S., Ganopolski, A., Claussen, M., 2000. Comparison of a coupled global model of intermediate complexity and an AOGCM for the Last Interglacial. Climate Dynamics 16, 799-814.

Kupriyanova, L.A., Alyoshina, L.A., 1972. Pollen and Spores of Plants from the Flora of European Part of USSR, vol. I.. Academy of Sciences USSR, Komarov Botanical Institute, Leningrad (in Russian).

Kupriyanova, L.A., Alyoshina, L.A., 1978. Pollen and Spores of Plants from the Flora of European Part of USSR. Academy of Sciences USSR, Komarov Botanical Institute Leningrad (in Russian).

Kuzmina, S.A., 2002. Quaternary insects of Yakutian coastal lowlands. PhD Thesis Palaeontological Institute, Moscow, p. 420 (in Russian).

Kuzmina, S., Sher, A., 2006. Some features of the Holocene insect faunas of northeastern Siberia. Quaternary Science Reviews 25, 1790-1820.

Kuznetsova, T., Starodubtseva, I.A., 2009. Wooly mammoths and history of the Laptev Sea coast and the New Siberian Islands. In: Kassens, H., Lisitzin, A.P. Polyakova, E.I., Timokhov, L.A., Frolov, I.E. (Eds.), System of Laptev Sea and the Adjacent Arctic Seas. Moscow University Press, Moscow, pp. 481-500.

Kuznetsova, T.V., Sulerzhitsky, L.D., Andreev, A.A., Siegert, C., Schirrmeister, L. Hubberten, H.-W., 2003. Influence of Late Quaternary paleoenvironmental conditions on the distribution of mammal's fauna in the Laptev Sea region. Occasional Papers in Earth Sciences 5, 58-60.

Kuznetsova, T., Schirrmeister, L., Noskova, N.G., 2004. Mammoth fauna collections from the Laptev Sea region in museums and institutes of the Russian Academy of Science. In: Kalabin, G.V., Bessudnova, Z.A., Kandinov, M.N., Starodubtseva, I.A. (Eds.), Problemy regional'noy geologii: muzeynyi rakurs. Akropol, Moscow, pp. 155-160 (in Russian).

Lambeck, K., Purcell, A., Funder, S., Kjær, K.H., Larsen, E., Moeller, P., 2006. Constraints on the Late Saalian to early Middle Weichselian ice sheet of Eurasia from field data and rebound modelling. Boreas 35, 539-575.

Lozhkin, A.V., Anderson, P.M., 1995. The Last Interglacial in northeast Siberia. Quaternary Research 43, 147-158. 
Lozhkin, A.V., Anderson, P.M., Matrosova, T.V., Minyuk, P.S., 2007. The pollen record from El'gygytgyn Lake: implications for vegetation and climate histories of northern Chukotka since the late middle Pleistocene. Journal of Paleolimnology 37, 135-153.

Makeyev, V.M., Ponomareva, D.P., Pitulko, V.V., Chernova, G.M., Solovyeva, D.V. 2003. Vegetation and climate of New Siberian Islands for the past 15000 years. Arctic, Antarctic and Alpine Research 35, 28-35.

Matrosova, T.V., 2009. Vegetation and climate change in northern Chukotka during the last $350 \mathrm{ka}$ basing on lacustrine pollen records from El'gygytgyn Lake. Vestnik FEB RAS 2, 23-30 (in Russian).

Meyer, H., Dereviagin, A., Siegert, C., Schirrmeister, L., Hubberten, H.-W., 2002a. Palaeoclimate reconstruction on Big Lyakhovsky Island, North Siberia hydrogen and oxygen isotopes in ice wedges. Permafrost and Periglacial Processes 13, 91-105.

Meyer, H., Derevyagin, A., Siegert, C., Hubberten, H.-W., 2002b. Paleoclimate studies on Bykovsky Peninsula, Northern Siberia hydrogen and oxygen isotopes in ground ice. Polarforschung 70, 37-51.

Meyer, H., Schirrmeister, L., Andreev, A., Wagner, D., Hubberten, H.-W. Yoshikawa, K., Bobrov, A., Wetterich, S., Opel, T., Kandiano, E., Brown, J., 2010. Lateglacial and Holocene isotopic and environmental history of northern coastal Alaska - results from a buried ice-wedge system at Barrow. Quaternary Science Reviews 29, 3720-3735. doi:10.1016/j.quascirev.2010.08.005.

Müller, S., Bobrov, A.A., Schirrmeister, L., Andreev, A.A., Tarasov, P.E., 2009a. Testate amoebae record from the Laptev Sea coast and its implication for the reconstruction of Late Pleistocene and Holocene environments in the Arctic Siberia. Palaeogeography, Palaeoclimatology, Palaeoecology 271, 301-315.

Müller, S., Tarasov, P.E., Andreev, A.A., Diekmann, B., 2009b. Lateglacial to Holocene environments in the present-day coldest region of the northern Hemisphere inferred from a pollen record of Lake Billyakh, Verkhoyansk Mts, NE Siberia. Climate of the Past 5, 73-84.

Müller, S., Tarasov, P.E., Andreev, A.A., Werner, K., Zech, M., Gartz, S., Diekmann, B. 2010. Late Quaternary vegetation and environments in the Verkhoyansk Mountains region (NE Asia) reconstructed from modern and fossil pollen data. Quaternary Science Reviews 29, 2071-2086.

Nowaczyk, N.R., Antonow, M., 1997. High-resolution magnetostratigraphy of four sediment cores from the Greenland Sea. I. Identification of the Mono Lake excursion, Laschamp and Biwa I/Jamaica geomagnetic polarity events. Geophysical Journal International 131, 310-324.

Petit, J.R., Jouzel, J., Raynaud, D., Barkov, N.I., Barnola, J.-M., Basile, I., Bender, M., Chappellaz, J., Davis, M., Delaygue, G., Delmotte, M., Kotlyakov, V.M., Lipenkov, V., Lorius, C., Pepin, L., Ritz, C., Saltzman, E., Stievenard, M., 1999. Climate and atmospheric history of the last 420000 years from the Vostok ice core, Antarctica. Nature 399, 429-436.

Petoukhov, V., Ganopolski, A., Brovkin, V., Claussen, M., Eliseev, A., Kubatzki, C. Rahmstorf, S., 2000. CLIMBER-2: a climate system model of intermediate complexity. Part I: model description and performance for present climate. Climate Dynamics $16,1-17$

Pirumova, L.G., Rybakova, N.O., 1984. The main stages of the late Cenozoic sedimentation in Northern Yakutia (according to data of spore-pollen and diatom analyses). In: Korotkiy, A.N. (Ed.), Paleogeograficheskie rubezhi i metody ikh izucheniya. DVNTs, Vladivostok, pp. 63-81 (in Russian).

Pisaric, M.F.J., MacDonald, G.M., Velichko, A.A., Cwynar, L.C., 2001. The Lateglacial and postglacial vegetation history of the northwestern limits of Beringia, based on pollen, stomate and tree stump evidence. Quaternary Science Reviews 20, 235-245.

Pitulko, V.V., Nikolsky, P.A., Girya, E.Y., Basilyan, A.E., Tumskoy, V.E., Koulakov, S.A., Astakhov, S.N., Pavlova, E.Y., Anisimov, M.A., 2004. The Yana RHS site: human in the Arctic before the last glacial maximum. Science 303, 52-56.

Prentice, I.C., Cramer, W., Harrison, S.P., Leemans, R., Monserud, R.A., Solomon, A.M. 1992. A global biome model based on plant physiology and dominance, soil properties and climate. Journal of Biogeography 19, 117-134.

Reille, M., 1992. Pollen et spores d'Europe et d'Afrique du nord. Laboratoire de Botanique Historique et Palynologie, Marseille.

Reille, M., 1995. Pollen et spores d'Europe et d'Afrique du nord, supplement 1. Laboratoire de Botanique Historique et Palynologie, Marseille.

Reille, M., 1998. Pollen et spores d'Europe et d'Afrique du nord, supplement 2. Laboratoire de Botanique Historique et Palynologie, Marseille.

Rybakova, N.O., 1962. Micropaleobotanical characteristic of Quaternary deposits in Arctic Yakutia. Vestnik Moskovskogo Universiteta 6, 55-63 (in Russian).

Rybakova, N.O., Kolesnikov, S.F., 1983. New evidence on the Upper Cenozoic deposits in the coastal lowlands of Yakutia. Byulleten' Moskovskogo obshestva ispytateley prirody. Otdelenie Geologii 60, 83-88 (in Russian).

Schirrmeister, L., Oezen, D., Geyh, M.A., 2002a. 230Th/U dating of frozen peat Bol'shoy Lyakhovsky Island (North Siberia). Quaternary Research 57, 253-258.

Schirrmeister, L., Siegert, Ch., Kuznetsova, T., Kuzmina, T., Andreev, A.A., Kienast, F. Meyer, H., Bobrov, A.A., 2002b. Paleoenvironmental and paleoclimatic records from permafrost deposits in the Arctic region of Northern Siberia. Quaternary International 89, 97-118.

Schirrmeister, L., Kunitsky, V.V., Grosse, G., Schwamborn, G., Andreev, A.A., Meyer, H., Kuznetsova, T., Bobrov, A., Oezen, D., 2003. Late Quaternary history of the accumulation plain north of the Chekanovsky Ridge (North east Yakutia). Polar Geography 27, 277-319.

Schirrmeister, L., Grosse, G., Kunitsky, V., Magens, D., Meyer, H., Dereviagin, A. Kuznetsova, T., Andreev, A., Babiy, O., Kienast, F., Grigoriev, M., Overduin, P.P. Preusser, F., 2008. Periglacial landscape evolution and environmental changes of Arctic lowland areas for the last 60000 years (western Laptev Sea coast, Cape Mamontov Klyk). Polar Research 272, 249-272.

Schirrmeister, L., Grosse, G., Andreev, A., Kunitsky, V., Fuchs, M.C., Krbetschek, M., Herzschuh, U., Babiy, O., Wetterich, S., Siegert, C., Meyer, H., Derevyagin, A., 2010. The mystery of BungeLand (New Siberian Archipelago) - Implications for its formation based on composite palaeo-environmental records, geomorphology and remote sensing. Quaternary Science Reviews 29, 3598-3614. doi:10.1016/j.quascirev.2009.11.017.

Schirrmeister, L., Kunitsky, V.V., Grosse, G., Wetterich, S., Meyer, H., Schwamborn, G., Babiy, O., Derevyagin, A.Y., Siegert, C. Sedementary characteristics and origin of the Late Pleistocene Ice Complex on North-East Siberian Arctic coastal lowlands and islands - a review. Quaternary International. in press. doi:10.1016/j.quaint. 2010.04.004

Schirrmeister, L., Grosse, G., Schnelle, M., Fuchs, M., Ullrich, M., Kunitsky, V., Krbetschek, M., Grigoriev, M., Andreev, A., Kienast, F., Meyer, H., Babiy, O., Klimova, I., Bobrov, A., Wetterich, S., Schwamborn, G, 2011. Late Quaternary paleoenvironmental records from the western Lena Delta, arctic Siberia. Palaeogeography, Palaeoclimatology, Palaeoecology 299, 175-196. doi:10.1016/ j.quascirev.2009.11.017.

Schuur, E., Vogel, J., Crummer, K., Lee, H., Sickman, J., Osterkamp, T., 2009. The effect of permafrost thaw on old carbon release and net carbon exchange from tundra. Nature 459, 556-559.

Sher, A.V., 1971. Mammals and Pleistocene Stratigraphy of the Extreme Northeast of the USSR and North America. Nauka, Moscow (in Russian).

Sher, A.V., 1991. Problems of the Last Interglacial in Arctic Siberia. Quaternary International 10-12, 215-222.

Sher, A.V., 1997. Environmental reconstructing at the Pleistocene/Holocene boundary in the east Siberian Arctic and its role in mammalian extinction and establishment of modern ecosystems (communication I). Kriosfera Zemli 1, 21-29 (in Russian).

Sher, A.V., Plakht, I.R., 1988. Radiocarbon dating and problems of the Pleistocene stratigraphy in lowlands of the Northeast USSR. International Geology Review 30, 853-867.

Sher, A.V., Kaplina, T.N., Ovander, M.G., 1987. Unified regional stratigraphic chart for the Quaternary deposits in the Yana-Kolyma lowland and its mountainous surroundings. Explanatory Note. In: Shilo, N.A. (Ed.), Resheniya mezhvedomstvennogo stratigraficheskogo soveshaniya po chetvertichnoy sisteme Vostoka SSSR. Magadan, 1982: Ob'yasnitel'nye zapiski k regional'nym stratigraficheskim skhemam. Far-Eastern Branch, North-Eastern Complex Research Institute, USSR Academy of Sciences, Magadan, pp. 29-69 (in Russian).

Sher, A.V., Kuzmina, S.A., Kuznetsova, T.V.,Sulerzhitsky, L.D., 2005. New insights into the Weichselian environment and climate of the Eastern-Siberian Artic, derived from fossil insects, plants, and mammals. Quaternary Science Reviews 24, 533-569.

Sirocko, F., Claussen, M., Litt, T., Sanchez-Goni, M.F. (Eds.), 2007. The Climate of Past Interglacials. Developments in Quaternary Science, vol. 7. Elsevier.

Stockmarr, J., 1971. Tablets with spores used in absolute pollen analysis. Pollen et Spores 13, 614-621.

Svendsen, J.I., Alexanderson, H., Astakhov, V.I., Demidov, I., Dowdeswell, J.A Funder, S., Gataullin, V., Henriksen, M., Hjort, C., Houmark-Nielsen, M. Hubberten, H.-W., Ingolfsson, O., Jacobsson, M., Kjær, K., Larsen, E., Lokrantz, H., Lunkka, J.P., Lysa, A., Mangerud, J., Matioushkov, A., Murray, A., Moeller, P., Niessen, F., Nikolskaya, O., Polyak, L., Saarnisto, M., Siegert, C., Siegert, M.J., Spielhagen, R.F., Stein, R., 2004. Late Quaternary ice sheet history of northern Eurasia. Quaternary Science Reviews 23, 1229-1272.

Tarasov, P., Granoszewski, W., Bezrukova, E., Brewer, S., Nita, M., Abzaeva, A., Oberhänsli, H., 2005. Quantitative reconstruction of the Last Interglacial vegetation and climate based on the pollen record from Lake Baikal, Russia. Climate Dynamics 25, 625-637.

Tarasov, P., Bezrukova, E., Karabanov, E., Nakagawa, T., Wagner, M., Kulagina, N., Letunova, P., Abzaeva, A., Granoszewski, W., Riedel, F., 2007. Vegetation and climate dynamics during the Holocene and Eemian interglacials derived from Lake Baikal pollen records. Palaeogeography, Palaeoclimatology, Palaeoecology 252, 440-457.

Tarasov, P.E., Bezrukova, E.V., Krivonogov, S.K., 2009. Lateglacial and Holocene changes in vegetation cover and climate in southern Siberia derived from a $15 \mathrm{kyr}$ long pollen record from Lake Kotokel. Climate of the Past 5, 73-84.

Van Geel, B., 2001. Non-pollen palynomorphs. In: Smol, J.P., Birks, H.J.B., Last, W.M., Bradley, R.S., Alverson, K. (Eds.), Tracking Environmental Change Using Lake Sediments. Terrestrial, Algal and Silicaceous Indicators, vol. 3. Kluwer, Dordrecht, pp. 99-119.

Vangengeim, E.A., 1977. Paleontologicheskoe obosnovanie stratigrafii antropogena Severnoi Azii (Paleontological substantiation of the Anthropogene stratigraphy of Northern Asia). Nauka, Moscow (in Russian).

Velichko, A.A., Nechaev, V.P. (Eds.), 2005. Cenozoic Climatic and Environmental Changes in Russia. Geological Society of America Special Paper 382.

Walter, K.M., Edwards, M.E., Grosse, G., Zimov, S.A., Chapin, F.S., 2007. Thermokarst lakes as a source of atmospheric $\mathrm{CH}_{4}$ during the last deglaciation. Science 318, 633-636.

Wetterich, S., Schirrmeister, L., Pietrzeniuk, E., 2005. Freshwater ostracods in Quaternary permafrost deposits from the Siberian Arctic. Journal of Paleolimnology 34, 363-376.

Wetterich, S., Kuzmina, S., Andreev, A.A., Kienast, F., Meyer, H., Schirrmeister, L., Kuznetsova, T., Sierralta, M., 2008. Palaeoenvironmental dynamics inferred from late Quaternary permafrost deposits on KurungnakhIsland (Lena Delta, northeast Siberia, Russia). Quaternary Science Reviews 27, 1523-1540. 
Wetterich, S., Schirrmeister, L., Andreev, A.A., Pudenz, M., Plessen, B., Meyer, H., Kunitsky, V.V., 2009. Eemian and Lateglacial/Holocene palaeoenvironmental records from permafrost sequences at the Dmitry Laptev Strait (NE Siberia, Russia). Palaeogeography, Palaeoclimatology, Palaeoecology 279, 73-95.

Wicklow, D.T., 1981. The coprophilous fungal community: a mycological system for examining ecological ideas. In: Wicklow, D.T., Carroll, G.C. (Eds.), The Fungal Community, Its Organization and Role in the Ecosystem. Dekker, New York, pp. $47-76$.

Williams, P.J., Warren, I.M.T., 1999. English Language Version of the Geocryological Map of Russia and Its Neighbouring Republics. Collaborative Map Project (Ottawa, Canada).

Winterfeld, M., Schirrmeister, L., Grigoriev, M., Kunitsky, V. V., Andreev, A., Overduin, P.P. Permafrost and landscape dynamics during the Late Pleistocene, western Laptev Sea shelf, Siberia. Boreas, in press, doi:10.1111/j.1502-3885.2011.00203.x.
Yurtsev, B.A., 2001. The Pleistocene tundra-steppe and the productivity paradox: the landscape approach. Quaternary Science Reviews 20, 165-174.

Zech, M., Andreev, A., Zech, R., Müller, S., Hambach, U., Frechen, M., Zech, W., 2010. Quaternary vegetation changes derived from a permafrost palaeosol sequence in NE-Siberia using alkane biomarker and pollen analyses: contradicting vegetation history versus climate history? Boreas $39,540-550$.

Zech, W., Zech, R., Leiber, K., Dippolt, M., Frechen, M., Bussert, R., Andreev, A. Obliquity forcing of Quaternary glaciation and environmental changes in $\mathrm{NE}$ Siberia. Quaternary International. in press. doi:10.1016/j.quaint.2010.04.016.

Zimov, S.A., Davydov, S.P., Zimova, G.M., Davydova, A.I., Schuur, E.A.G., Dutta, K., Chapin, F.S., 2006a. Permafrost carbon: Stock and decomposability of a globally significant carbon pool. Geophysical Research Letters 33, L20502.

Zimov, S.A., Schuur, E.A.G., Chapin, F.S., 2006b. Permafrost and the global carbon budget. Science 312, 1612-1613. 